\title{
Reversal of Retinal Vascular Changes Associated with Ocular Neovascularization by Small Molecules: Progress toward Identifying Molecular Targets for Therapeutic Intervention
}

\author{
Michael DeNiro*,1,2 and Futwan Al-Mohanna ${ }^{3}$ \\ ${ }^{I}$ Research Dept., King Khaled Eye Specialist Hospital, Riyadh, Saudi Arabia \\ ${ }^{2}$ Dept. of Comparative Medicine, ${ }^{3}$ Dept. of Biological and Medical Research, King Faisal Specialist Hospital \& \\ Research Centre, Riyadh, Saudi Arabia
}

\begin{abstract}
The elucidation of the molecular pathogenesis of ocular disease provides candidate targets for treatment. Animal models allow for identification and quantitation of ocular diseases. By gaining insight regarding the molecular signals involved in various types of ocular angiogenesis, general concepts can emerge that may apply to other settings, including tumor angiogenesis. The hypoxia inducible factor-1 (HIF-1) pathway is relatively well understood and serves as a good example of how knowledge of the biological responses to hypoxia can translate into new therapies. Furthermore, HIF pathway can be used as a therapeutic target and that the manipulation of the HIF pathway at several points has potential use for the treatment of oxygen-dependent diseases in retina. However, there are numerous other molecular and cellular responses to hypoxia that are independent of HIF-1, perhaps each with unique oxygen sensors. Despite participation of multiple stimulatory factors for ocular neovascularization (NV), vascular endothelial growth factor (VEGF) emerges as a pivotal player, thus manipulation of VEGF signaling represents an important therapeutic strategy. While most studies have focused on prevention of ocular NV, regression of new vessels is desirable and is achievable with various small molecules. Screens are underway to identify and test the efficacy of these small-molecules to target various mechanisms involved in ocular NV. These small molecules might represent an important component of novel combination therapies to target various molecular signaling mechanisms in neovascular tissues.
\end{abstract}

Keywords: Antiangiogenic drugs, neovascularization, reversal, small molecules, HIF-1, YC-1.

\section{INTRODUCTION}

Diabetic retinopathy (DR) is a leading cause of visual disturbance in adults. In the early stage of the disease, retinal vascular permeability can increase even before the appearance of clinical retinopathy [1]. Retinal vascular leakage and thickening of the retina lead to diabetic macular edema (DME). In the late stage of DR, abnormal increases in vascular permeability result from retinal ischemia due to nonperfusion of the retina or a decrease in oxygen tension [2]. During this stage, over-proliferation of capillary endothelial cells (ECs) results in retinal NV, abnormal formation of new vessels in the retina and in the vitreous, leading to proliferative diabetic retinopathy (PDR) [3]. Additionally, during the late stages of DR, the ischemiainduced pathological angiogenesis ultimately causes severe vitreous cavity bleeding and/or retinal detachment, resulting in severe loss of vision.

Retinal NV is the major cause of severe vision loss and irreversible blindness in developed countries, affecting people of all ages. These clinical and pathologic manifestations occur in DR, retinopathy of prematurity (ROP), age-related macular degeneration (AMD) and retinal

*Address correspondence to this author at the Research Dept., King Khaled Eye Specialist Hospital, Riyadh, Saudi Arabia; Tel: (966) 55-787-5950; Fax: (966-1) 482-9311; E-mail: mdeniro@kkesh.med.sa vein occlusion (RVO). Angiogenic factors, such as VEGF, play a prominent role in promoting retinal NV. Retinal ischemia is the major driving force behind the induction of VEGF, which plays a crucial role in ocular pathogenesis [4]. VEGF has a profound impact on multiple functions in ECs, such as proliferation, migration, survival, tube formation, and vascular permeability [5]. Previous studies have indicated that VEGF is an important mediator of $\mathrm{NV}$ induced by hypoxic retinopathies [6]. It has been reported that there is increased VEGF production in both vitreous [7], and ocular fluids [8] of patients with DR. Suppression of VEGF receptor interaction, VEGF expression and VEGF-induced signaling has been shown to inhibit NV in animal models of retinal ischemia [9] (Fig. 4).

Screens are underway to identify and test the efficacy of various small molecules to target a plethora of signaling pathways that contribute to ocular NV. YC-1; (3-(5'hydroxymethyl-2'furyl)-1-benzyl indazole], is a small molecule that inhibits cGMP breakdown and potentiates nitric oxide (NO)-induced soluble guanylyl cyclase (sGC) stimulation [10]. Data from our lab have revealed that YC-1 suppressed retinal new vessel growth and formation in human retinal microvascular ECs, and retinal explants. Furthermore, we have demonstrated that YC-1 downregulates HIF-1 $\alpha$, HIF-2 $\alpha$, VEGF, erythropoietin (EPO), endothelin-1 (ET-1), and matrix metalloproteinase-9 (MMP9) protein levels in the human retinal microvascular ECs [11, 12 ]. In addition, oxygen induced retinopathy (OIR) mouse 


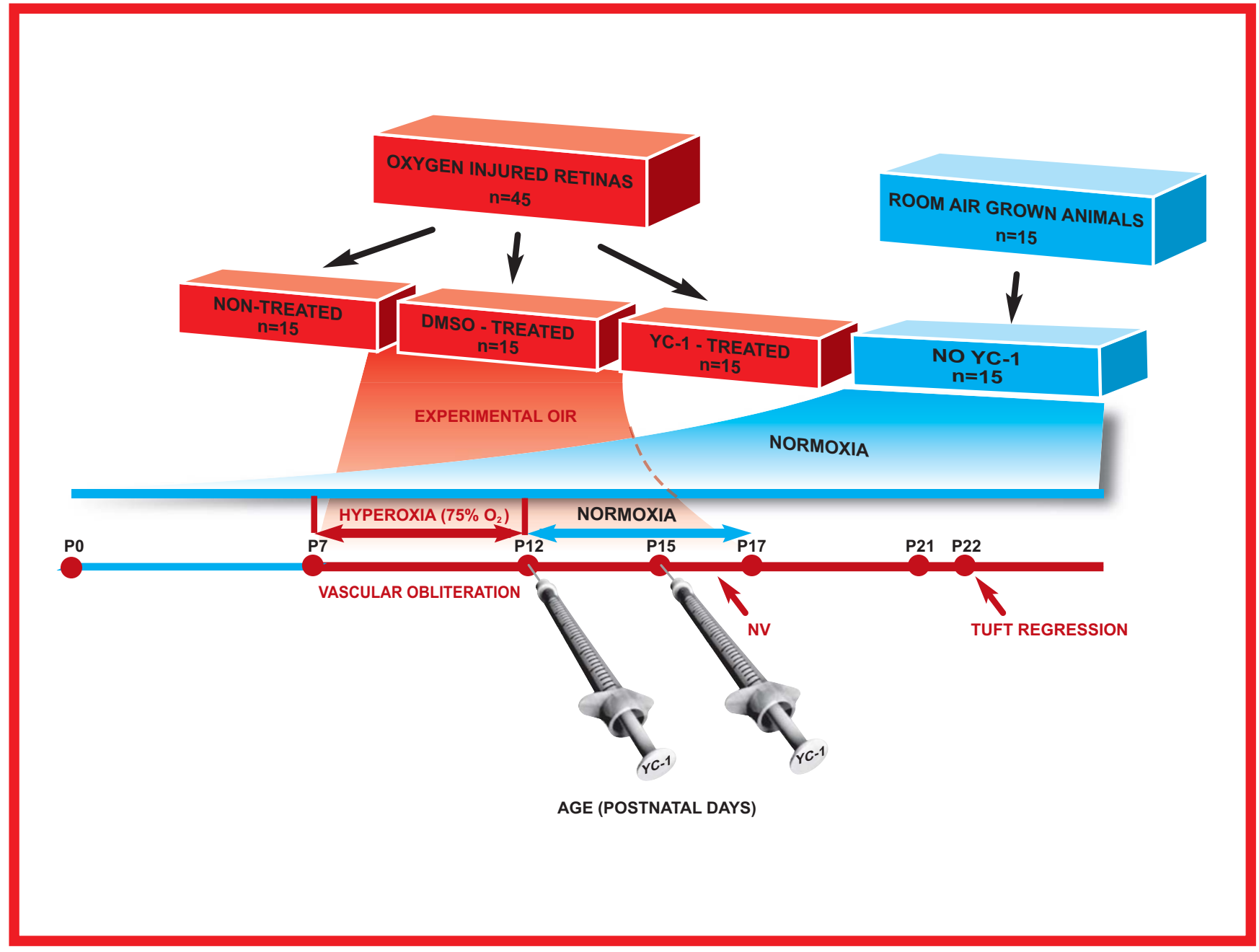

Fig. (1). Timeline of Study of Retinal Vasculature during Normal Development and OIR. The diagram was based on the protocol, which was developed by [13]. Mice were placed in $75 \% \mathrm{O}_{2}$ between P7 and P12. Mice were returned to room air on P12, which triggered a relative ischemic condition in the retina. The retina then exhibited pathologic growth of vessels in the superficial layer; with pre-retinal vascular tufts that extended through the ILM into the vitreous. Double intravitreal injections of YC-1 (100 $\mu \mathrm{M})$ were injected, immediately after removal from 5-day treatment of 75\% oxygen, on P12 and P15. Mice were sacrificed on P12, P15, P17, P21, and P22. Solid Blue Line, normal vessel growth under ambient conditions; Solid Red Line, vessel growth under OIR conditions; Needles, YC-1-injections time points.

model [13] and (Fig. 1) has produced several clinical manifestations that resemble the ones that are exhibited during the diabetes-induced retinopathies. Our data have revealed for the first time that YC-1 selectively inhibits retinal NV (Fig. 2B), while concomitantly promotes physiological revascularization in a mouse model of OIR [14]. Retinal treatment with YC-1 induced the reversal of the vasculature growth to a state that was comparable to the normal retinas that were grown under normoxic conditions (Figs. 1, 2A). There are various small molecules that are currently in use to treat patients with ocular pathologies (Table 1). In this review, we will attempt to shed some light on these molecules and the role that they play in targeting a wide range of signaling pathways that are relevant to ocular $\mathrm{NV}$ in different tissues and in animal models.

\section{INHIBITORS OF VASCULAR ENDOTHELIAL GROWTH FACTOR (VEGF)}

The concept that growth factors mediate retinal angiogenesis was postulated by Michaelson in 1948 [15]. More recently, attention has focused on VEGF as the primary mediator of intraocular angiogenesis and permeability in PDR [as well as in other conditions, including; DME, exudative AMD, RVO, and ROP]. Several features of VEGF make it a plausible mediator of retinal NV and vascular permeability in ischemic ocular conditions. It is produced by numerous types of ocular cells, including retinal ECs, which in addition express abundant VEGF receptors. Furthermore, VEGF expression is markedly increased in response to hypoxia, and is a potent inducer of vasopermeability [16]. Consequently, the retina may become 
(A)

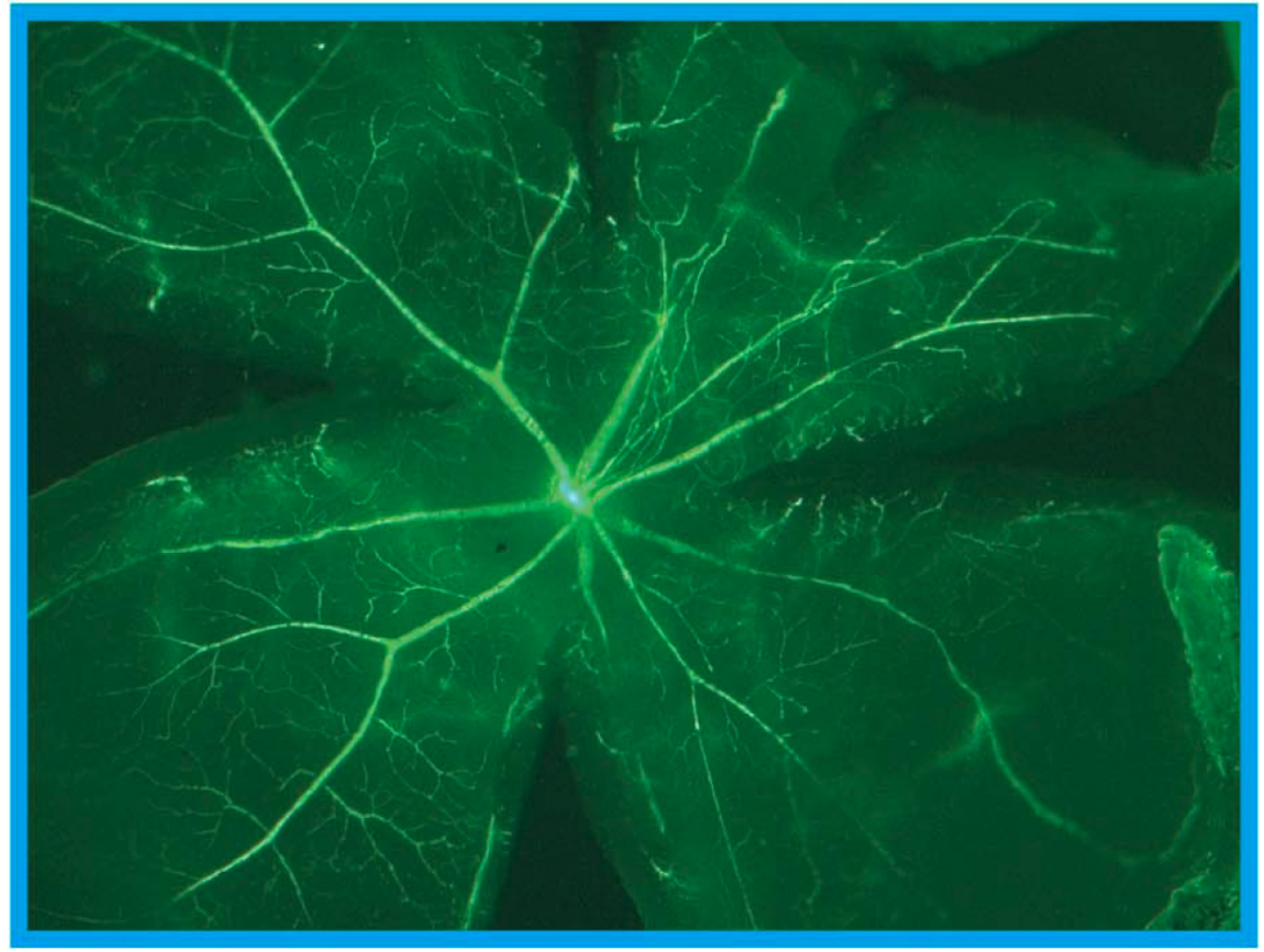

(B)

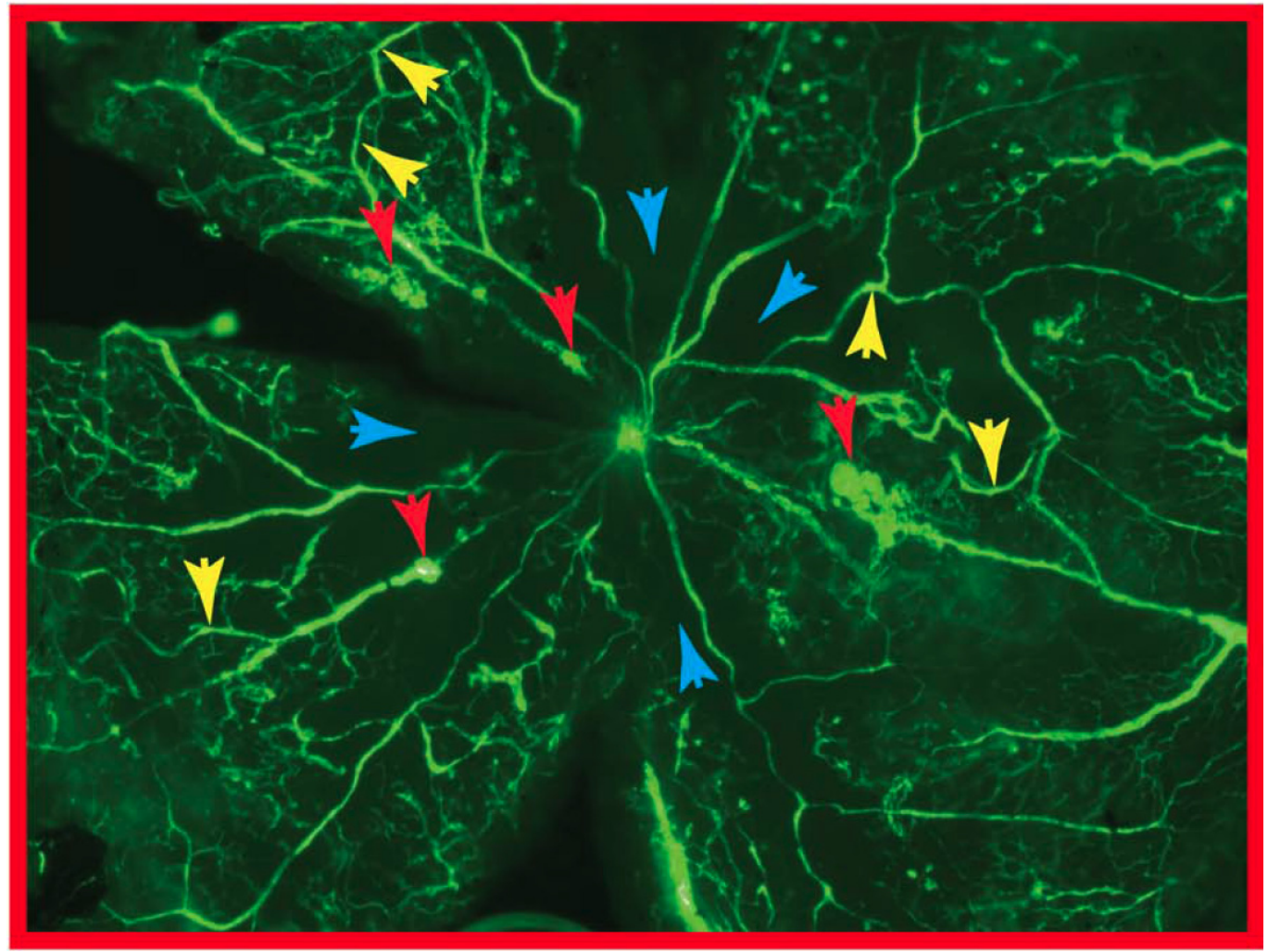

Fig. (2). (A) Retina from P17 "control" room air-reared mouse shows a homogeneous normal delicate vessel pattern throughout the retina. The retina is completely vascularized without avascularized areas. No blood vessel tufts are present. The main vessels show no tortuosity and no dilation. (B) Retina from P17 non-treated oxygen-injured group shows an engorged tortuous appearance of the blood vessels, large central avascular area (yellow arrows), and high presence of blood vessel tufts (red arrows). 
Table 1. Antiangiogenic Drugs, Current Strategies, and Multiple Pathways for the Treatment of Ocular Pathologies

\begin{tabular}{|c|c|c|c|c|c|c|c|c|}
\hline sGC & YC-1 & $\begin{array}{l}\text { inhibit cGMP } \\
\text { degradation/ } \\
\text { potentiate }\end{array}$ & OIR & mouse & & & $\begin{array}{c}\text { DeNiro } \\
\text { et al., } \\
\text { 2009b;2010 }\end{array}$ & $\begin{array}{c}\text { Potential } \\
\text { Treatment } \\
\text { of Retinal NV }\end{array}$ \\
\hline \multirow[t]{5}{*}{ VEGF } & $\begin{array}{c}\text { Bevacizumab } \\
\text { (Avastin) }\end{array}$ & $\begin{array}{l}\text { mAb to } \\
\text { VEGF-A }\end{array}$ & $\begin{array}{l}\text { Colon } \\
\text { Cancer }\end{array}$ & mouse & & & $\begin{array}{l}\text { Warren } \\
\text { et al., } \\
1995\end{array}$ & $\begin{array}{l}\text { Treatment of } \\
\text { Colon Cancer }\end{array}$ \\
\hline & $\begin{array}{l}\text { Bevacizumab } \\
\text { (Avastin) }\end{array}$ & $\begin{array}{l}\text { mAb to } \\
\text { VEGF-A }\end{array}$ & $\begin{array}{l}\text { DR and } \\
\text { DME }\end{array}$ & human & inravitreal & & $\begin{array}{l}\text { Friedlander } \\
\text { et al., } \\
2002\end{array}$ & $\begin{array}{l}\text { Treatment of } \\
\text { DME in CVO }\end{array}$ \\
\hline & $\begin{array}{c}\text { Aflibercept } \\
\text { (VEGF-TRAP) }\end{array}$ & $\begin{array}{l}\text { Binds All } \\
\text { Forms of } \\
\text { VEGF and } \\
\text { PLGF }\end{array}$ & $\begin{array}{l}\text { Solid } \\
\text { Tumor }\end{array}$ & human & systemic & Phase I & $\begin{array}{l}\text { Lockhart } \\
\text { et al., } \\
2010\end{array}$ & $\begin{array}{l}\text { Treatment of } \\
\text { Neovascular } \\
\text { (wet) AMD }\end{array}$ \\
\hline & $\begin{array}{c}\text { Cand5 } \\
\text { (bevasiranib) }\end{array}$ & siRNA & $\begin{array}{l}\mathrm{NV} \text { and } \\
\text { Vessel } \\
\text { Leakage }\end{array}$ & Primate & Intravitreal & & $\begin{array}{l}\text { Tolentino } \\
\text { et al., } \\
2004\end{array}$ & $\begin{array}{l}\text { Treatment of } \\
\text { Neovascular } \\
\text { (wet) AMD }\end{array}$ \\
\hline & AGN211745 & siRNA & AMD & Human & Intravitreal & Phase II & $\begin{array}{l}\text { Allergan; } \\
2008\end{array}$ & $\begin{array}{c}\text { Treatment of } \\
\text { subfoveal CNV } \\
\text { associated with } \\
\text { AMD }\end{array}$ \\
\hline \multirow{6}{*}{$\begin{array}{l}\text { Tyrosine } \\
\text { Kinase }\end{array}$} & Sorafenib & $\begin{array}{l}\text { multi kinase } \\
\text { inhibitor }\end{array}$ & $\begin{array}{l}\text { VEGF-A } \\
\text { culture cell }\end{array}$ & human & & & $\begin{array}{l}\text { Kernt } \\
\text { et al., } \\
2010\end{array}$ & $\begin{array}{l}\text { Treatment of } \\
\text { Neovascular } \\
\text { (wet) AMD }\end{array}$ \\
\hline & Pazopanib & $\begin{array}{l}\text { multi kinase } \\
\text { inhibitor }\end{array}$ & $\mathrm{CNV}$ & mouse & oral & & $\begin{array}{l}\text { Takahashi } \\
\text { et al., } \\
2009\end{array}$ & $\begin{array}{c}\text { Potential } \\
\text { Treatment for } \\
\text { CNV }\end{array}$ \\
\hline & AG013711 & $\begin{array}{l}\text { VEGFR-1, } \\
\text { VEGFR-2, } \\
\text { PDGFR } \\
\text { inhibitor }\end{array}$ & $\mathrm{CNV}$ & rat & intravitreal & & $\begin{array}{l}\text { Wang } \\
\text { et al., } \\
2007\end{array}$ & $\begin{array}{c}\text { Potential } \\
\text { Treatment for } \\
\text { CNV }\end{array}$ \\
\hline & AG013764 & $\begin{array}{l}\text { VEGFR-1, } \\
\text { VEGFR-2, } \\
\text { PDGFR } \\
\text { inhibitor }\end{array}$ & $\mathrm{CNV}$ & rat & intravitreal & & $\begin{array}{l}\text { Wang } \\
\text { et al., } \\
2007\end{array}$ & $\begin{array}{c}\text { Potential } \\
\text { Treatment for } \\
\text { CNV }\end{array}$ \\
\hline & AG013958 & $\begin{array}{l}\text { VEGFR-1, } \\
\text { VEGFR-2, } \\
\text { PDGFR } \\
\text { inhibitor }\end{array}$ & AMD & human & sub Tenon & & $\begin{array}{l}\text { Hoyng } \\
\text { et al., } \\
2005\end{array}$ & $\begin{array}{c}\text { Halted Trial } \\
\text { Treatment of } \\
\text { the Teal CNV } \\
\text { assoc. with AMD }\end{array}$ \\
\hline & PKC412 & $\begin{array}{l}\text { inhibit } \\
\text { VEGFR, } \\
\text { PDGFR, } \\
\text { c-kit, PKC }\end{array}$ & $\begin{array}{l}\text { proliferative } \\
\text { retinopathy }\end{array}$ & mouse & oral & & $\begin{array}{l}\text { Saishin } \\
\text { et al., } \\
2003\end{array}$ & $\begin{array}{c}\text { Potential } \\
\text { Treatment for } \\
\text { wet AMD }\end{array}$ \\
\hline
\end{tabular}


(Table 1) contd.....

\begin{tabular}{|c|c|c|c|c|c|c|c|c|}
\hline Target & Compound & $\begin{array}{c}\text { Mechanism } \\
\text { of Action }\end{array}$ & $\begin{array}{l}\text { Disease } \\
\text { (Model) }\end{array}$ & Species & Route & $\begin{array}{l}\text { Clinical } \\
\text { Use }\end{array}$ & Refs. & Clinical Relevance \\
\hline & $\begin{array}{c}\text { Vatalanib } \\
\text { (PTK787/ZK222584) }\end{array}$ & $\begin{array}{l}\text { inhibit } \\
\text { VEGFR, } \\
\text { PDGFR, } \\
\text { c-kit }\end{array}$ & $\begin{array}{l}\text { Subretinal } \\
\text { NV }\end{array}$ & mouse & $\begin{array}{l}\text { Intraocular } \\
\text { Injection }\end{array}$ & & $\begin{array}{l}\text { Ozaki } \\
\text { et al., } \\
2000\end{array}$ & $\begin{array}{l}\text { Potential } \\
\text { Treatment } \\
\text { for CNV due } \\
\text { to AMD }\end{array}$ \\
\hline & JNJ-17029259 & $\begin{array}{l}\text { VEGFR-2 } \\
\text { inhibitor }\end{array}$ & $\begin{array}{c}\text { cancer } \\
\text { xenograft }\end{array}$ & mouse & oral & & $\begin{array}{l}\text { Emanuel } \\
\text { et al., } \\
2004\end{array}$ & $\begin{array}{c}\text { Delays the } \\
\text { Growth of a } \\
\text { Wide Range of } \\
\text { Human Tumor }\end{array}$ \\
\hline & TG100572 & $\begin{array}{l}\text { VEGFR-2, } \\
\text { PDGFR, } \\
\text { FGFR } \\
\text { inhibitor }\end{array}$ & $\mathrm{CNV}$ & mouse & topical & & $\begin{array}{l}\text { Scheppke } \\
\text { et al., } \\
2008\end{array}$ & $\begin{array}{c}\text { Potential Treatment } \\
\text { of Neovascular } \\
\text { AMD }\end{array}$ \\
\hline & TG100801 & $\begin{array}{l}\text { pro-drug of } \\
\text { TG100572 }\end{array}$ & AMD & human & topical & Phase I & $\begin{array}{l}\text { TargeGen; } \\
2010\end{array}$ & $\begin{array}{c}\text { Treatment of } \\
\text { AMD, DR, } \\
\text { DME }\end{array}$ \\
\hline & SU10944 & $\begin{array}{l}\text { VEGFR-2 } \\
\text { inhibitor }\end{array}$ & $\begin{array}{l}\text { cornea } \\
\text { micro } \\
\text { pocket } \\
\text { model }\end{array}$ & rat & oral & & $\begin{array}{l}\text { Patel } \\
\text { et al., } \\
2003\end{array}$ & $\begin{array}{l}\text { Potential to } \\
\text { ameliorate NV } \\
\text { and Vascular } \\
\text { Permeability }\end{array}$ \\
\hline & ZM323881 & $\begin{array}{l}\text { VEGFR-2, } \\
\text { PDGFR, } \\
\text { FGFR1 } \\
\text { inhibitor }\end{array}$ & & $\begin{array}{c}\text { human } \\
\text { aorticendothelial } \\
\text { cells }\end{array}$ & & & $\begin{array}{l}\text { Endo } \\
\text { et al., } \\
2003\end{array}$ & $\begin{array}{c}\text { Potential } \\
\text { Treatment for } \\
\text { Ischemia-Induced } \\
\text { Retinal NV }\end{array}$ \\
\hline \multirow[t]{4}{*}{$\begin{array}{l}\text { Other } \\
\text { Kinase }\end{array}$} & LY294002 & $\begin{array}{l}\text { PI3K } \\
\text { inhibitor }\end{array}$ & $\begin{array}{l}\text { hypoxia } \\
\text { and notch } \\
\text { inhibitor }\end{array}$ & zebrafish & systemic & & $\begin{array}{l}\text { Alvarez } \\
\text { et al., } \\
2009\end{array}$ & $\begin{array}{l}\text { Potential } \\
\text { Treatment } \\
\text { to Inhibit } \\
\text { Retinal NV }\end{array}$ \\
\hline & SRPIN340 & $\begin{array}{l}\text { SPK1/2 } \\
\text { inhibitor }\end{array}$ & $\mathrm{CNV}$ & mouse & intravitreal & & $\begin{array}{l}\text { Hua } \\
\text { et al., } \\
2009\end{array}$ & $\begin{array}{c}\text { Potential } \\
\text { treatment to } \\
\text { Inhibit NV } \\
\text { and Increased } \\
\text { RV }\end{array}$ \\
\hline & TG003 & $\begin{array}{l}\text { Clk } \\
\text { inhibitor }\end{array}$ & $\begin{array}{c}\text { Retinal } \\
\text { Pigment } \\
\text { Epithelial Cells }\end{array}$ & & & & $\begin{array}{l}\text { Nowak } \\
\text { et al., } \\
2008\end{array}$ & $\begin{array}{c}\text { Potential } \\
\text { treatment } \\
\text { for NV }\end{array}$ \\
\hline & H-1152 & $\begin{array}{l}\text { Rho-kinase } \\
\text { inhibitor }\end{array}$ & OIR & mouse & $\begin{array}{c}\text { *increase } \\
\text { angiogenesis }\end{array}$ & & $\begin{array}{l}\text { Kroll J } \\
\text { et al., } \\
2009\end{array}$ & $\begin{array}{l}\text { Potential as } \\
\text { a New } \\
\text { Antiglaucoma } \\
\text { Medication }\end{array}$ \\
\hline \multirow[t]{2}{*}{ mTor } & Rapamycin & $\begin{array}{l}\text { mTor } \\
\text { inhibitor }\end{array}$ & $\mathrm{AMD}$ & human & oral & PhaseI/II & $\begin{array}{c}\text { Nussenblatt } \\
\text { et al., } \\
2010\end{array}$ & $\begin{array}{l}\text { Treatment of } \\
\text { Sub-Foveal } \\
\text { CNV Secondary } \\
\text { to AMD }\end{array}$ \\
\hline & $\begin{array}{c}\text { Perceiva } \\
\text { (sirolimus) }\end{array}$ & $\begin{array}{l}\text { mTor } \\
\text { inhibitor }\end{array}$ & AMD & human & $\begin{array}{l}\text { subconjunct. } \\
\text { or } \\
\text { intravitreally }\end{array}$ & Phase II & $\begin{array}{l}\text { MacuSight; } \\
2009\end{array}$ & $\begin{array}{l}\text { Treatment of } \\
\text { DME, Neovascular } \\
\text { (wet) AMD } \\
\text { and Dry Eye } \\
\text { Syndrome }\end{array}$ \\
\hline \multirow[t]{2}{*}{ Cell Cycle } & TNP-470 & $\begin{array}{c}\text { stop cell } \\
\text { cycle at G1 }\end{array}$ & $\mathrm{CNV}$ & rabbit & intravenous & & $\begin{array}{l}\text { Yasukawa } \\
\text { et al., } \\
1999\end{array}$ & $\begin{array}{c}\text { Potential } \\
\text { Treatment } \\
\text { for Choroidal } \\
\text { Neovascular } \\
\text { Membranes }\end{array}$ \\
\hline & IMS2186 & $\begin{array}{c}\text { stop cell } \\
\text { cycle at } \mathrm{G} 2\end{array}$ & $\mathrm{CNV}$ & rat & intravitreal & & $\begin{array}{c}\text { Falkenstein } \\
\text { et al., } \\
2008\end{array}$ & $\begin{array}{l}\text { Treatment of } \\
\text { Intraocular } \\
\text { Proliferation and } \\
\text { angiogenesis }\end{array}$ \\
\hline $\begin{array}{l}\text { Receptor } \\
\text { Binding }\end{array}$ & 5-amino-2-NMS & $\begin{array}{l}\text { FGF1 or } \\
\text { FGF2 }\end{array}$ & OIR & mouse & intravitreal & & $\begin{array}{l}\text { Lange } \\
\text { et al., } \\
2007\end{array}$ & $\begin{array}{c}\text { Potential } \\
\text { Treatment } \\
\text { of Retinal NV }\end{array}$ \\
\hline
\end{tabular}




\begin{tabular}{|c|c|c|c|c|c|c|c|c|}
\hline Target & Compound & $\begin{array}{l}\text { Mechanism } \\
\text { of Action }\end{array}$ & $\begin{array}{l}\text { Disease } \\
\text { (Model) }\end{array}$ & Species & Route & $\begin{array}{l}\text { Clinical } \\
\text { Use }\end{array}$ & Refs. & Clinical Relevance \\
\hline & $\begin{array}{l}\text { soluble Tie2 } \\
(\mathrm{sTie} 2-\mathrm{Fc})\end{array}$ & $\begin{array}{l}\text { block } \\
\text { Tie2 }\end{array}$ & $\mathrm{CNV}$ & mouse & $\begin{array}{l}\text { gene } \\
\text { therapy }\end{array}$ & & $\begin{array}{l}\text { Singh } \\
\text { et al., } \\
2005\end{array}$ & $\begin{array}{c}\text { Potential } \\
\text { Treatment of } \\
\text { Retinal NV }\end{array}$ \\
\hline Hsp90 & $\begin{array}{l}\text { Geldanamycin } \\
\text { (17-AAG) }\end{array}$ & $\begin{array}{l}\text { bind to } \\
\text { HSP90 }\end{array}$ & OIR & mouse & IP & & $\begin{array}{l}\text { Kociok } \\
\text { et al., } \\
2007\end{array}$ & $\begin{array}{l}\text { Potential } \\
\text { Treatment of } \\
\text { Retinal NV }\end{array}$ \\
\hline $\begin{array}{l}\text { PPAR } \\
\text { gamma }\end{array}$ & thiazolidinediones & $\begin{array}{c}\text { activate } \\
\text { PPARgamma }\end{array}$ & $\mathrm{CNV}$ & rat, monkey & intravitreal & & $\begin{array}{l}\text { Murata } \\
\text { et al., } \\
2000\end{array}$ & $\begin{array}{l}\text { Potential } \\
\text { Treatment of } \\
\text { Retinal NV }\end{array}$ \\
\hline Tubulin & $\begin{array}{l}\text { Combretastatin A-4 } \\
\text { (CA-4) }\end{array}$ & $\begin{array}{l}\text { bind } \\
\text { tubulin }\end{array}$ & $\begin{array}{l}\text { CNV, VEGF } \\
\text { overexpression }\end{array}$ & mouse & IP & & $\begin{array}{l}\text { Nambu } \\
\text { et al., } \\
2003\end{array}$ & $\begin{array}{l}\text { Potential } \\
\text { Treatment of } \\
\text { CNV }\end{array}$ \\
\hline Integrin & JSM6427 & $\begin{array}{l}\text { a5b1-FN } \\
\text { interaction } \\
\text { inhibitor }\end{array}$ & $\mathrm{CNV}$ & $\begin{array}{l}\text { rabbit, } \\
\text { monkey }\end{array}$ & intravireal & & $\begin{array}{l}\text { Zahn } \\
\text { et al., } \\
2009\end{array}$ & $\begin{array}{c}\text { Potential } \\
\text { Treatment of } \\
\text { ocular neovascular } \\
\text { diseases (AMD) }\end{array}$ \\
\hline \multirow[t]{2}{*}{ RAS } & Enalapril, Losartan & $\begin{array}{l}\text { inhibit } \\
\text { renin- } \\
\text { angiotensin } \\
\text { system }\end{array}$ & $\begin{array}{l}\text { diabetic } \\
\text { retinopathy }\end{array}$ & human & oral & & $\begin{array}{l}\text { Mauer } \\
\text { et al., } \\
2009\end{array}$ & $\begin{array}{l}\text { Slowed the } \\
\text { Progression of } \\
\text { Type I DR }\end{array}$ \\
\hline & Olmesartan & $\begin{array}{l}\text { block AT1 } \\
\text { receptor }\end{array}$ & OIR & rat & oral & & $\begin{array}{l}\text { Nakamura } \\
\text { et al., } \\
2009\end{array}$ & $\begin{array}{c}\text { Potential } \\
\text { Treatment to } \\
\text { inhibit } \\
\text { Vascular } \\
\text { Hyperpermeability }\end{array}$ \\
\hline \multirow[t]{2}{*}{$\begin{array}{c}\text { Growth } \\
\text { Factor }\end{array}$} & pegvisomant & $\begin{array}{c}\mathrm{GHr} \\
\text { antagonist }\end{array}$ & $\begin{array}{l}\text { diabetic } \\
\text { retinopathy }\end{array}$ & human & systemic & $\begin{array}{c}\text { no } \\
\text { regression }\end{array}$ & $\begin{array}{c}\text { GH } \\
\text { Antagonist } \\
\text { for PDR } \\
\text { Study } \\
\text { Group; } \\
2001\end{array}$ & $\begin{array}{l}\text { Ineffective for } \\
\text { the Treatment } \\
\text { of DR }\end{array}$ \\
\hline & Somatostatin Analogue & $\begin{array}{c}\text { Inhibits } \\
\text { IGF-1, } \\
\text { bFGF, and } \\
\text { VEGF } \\
\text { (Woc4D } \\
\text { and octreotide) }\end{array}$ & OIR & Mouse & intravitreal & & $\begin{array}{l}\text { Higgins } \\
\text { et al., } \\
2002\end{array}$ & $\begin{array}{l}\text { Nuroprotective } \\
\text { role in Models } \\
\text { of Retinal Disease; } \\
\text { Inhibition of } \\
\text { Retinal and } \\
\text { Corneal NV }\end{array}$ \\
\hline Inflammation & $\begin{array}{l}\text { Triamcinolone acetonide } \\
\text { (TCA) }\end{array}$ & $\begin{array}{c}\text { Inhibits VEGF, } \\
\text { ICAM-1, } \\
\text { inflammatory } \\
\text { cells, } \\
\text { upregulates } \\
\text { PEDF }\end{array}$ & $\begin{array}{l}\text { blood-retinal } \\
\text { and blood - } \\
\text { aqueous } \\
\text { barrier } \\
\text { breakdown }\end{array}$ & rabbit & & & $\begin{array}{l}\text { Edelman } \\
\text { et al., } \\
2005\end{array}$ & $\begin{array}{l}\text { Treatment of } \\
\text { DR, Uveitis, } \\
\text { CNV associated } \\
\text { with AMD, } \\
\text { and Ocular } \\
\text { edema associated } \\
\text { with CVO }\end{array}$ \\
\hline Angiogenesis & $\begin{array}{l}\text { Tryptophanyl-tRNA } \\
\text { synthetase } \\
\text { (TrpRS) }\end{array}$ & $\begin{array}{c}\text { Antagonist of } \\
\text { VEGF-Induced } \\
\text { Angiogenesis }\end{array}$ & $\begin{array}{c}\text { Postnatal } \\
\text { Mouse Retinal } \\
\text { Angiogenesis } \\
\text { Model }\end{array}$ & Mouse & Intravitreal & & $\begin{array}{l}\text { Otani } \\
\text { et al., } \\
2002\end{array}$ & $\begin{array}{c}\text { Potential } \\
\text { Applications } \\
\text { for Ocular } \\
\text { Neovascular } \\
\text { Disease/AMD }\end{array}$ \\
\hline
\end{tabular}


"ischemic", resulting in the growth of new abnormal blood vessels that can cause further vision loss and more serious complications. VEGF levels correlate closely with active intraocular NV and very high VEGF intraocular levels in patients with PDR decline after successful laser photocoagulation. These observations have led to the hypothesis that anti-angiogenic agents could be used to inhibit the development of proliferative retinopathy, much like their use in cancer, which was originally proposed by Folkman more than 30 years ago [17]. It is believed that antiVEGF treatment may help decrease vascular permeability and edema and prevent the growth of abnormal new blood vessels in the retina in patients with central retinal vein occlusion (CRVO). To date, most clinical trials of antiangiogenic therapy for ocular disease have focused on agents that specifically sequester VEGF, thus preventing VEGFreceptor engagement (Figs. 3, 4). Such agents include Avastin (bevacizumab), a recombinant humanized murine monoclonal antibody (MoAB) that binds to and inhibits the biologic activity of all human VEGF-A isoforms [18] (Fig. 3). Avastin inhibits all isoforms of VEGF by blocking its interaction with membrane-bound tyrosine kinase (TK) receptors VEGFR-1 and VEGFR-2 [19] (Figs. 3, 4). Thus inhibiting VEGF-induced cell proliferation, survival, permeability, nitric oxide production, migration, and tissue factor production [16]. Early preclinical work demonstrated activity against tumors from a human colorectal carcinoma (CRC) cell in mice [20], and phase I evaluations of Avastin revealed good tolerability when used alone and in combination with 5-fluorouracil (5-FU) and leucovorin (LV) [21]. Currently, Avastin is an FDA approved drug for intravenous use in the treatment of metastatic colorectal carcinoma. Furthermore, in the quest to help patients with neovascular AMD who do not respond to current therapies, injections of Avastin, as an off label intravitreal agent into the eye has been employed. Avastin has produced promising results in inhibiting NV in DR [22] and neovascular AMD $[23,24]$. When administered into the vitreous cavity, Avastin penetrates the retina and disperse through the retinal pigment epithelium (RPE) and into the choroid, scavenging extracellular VEGF molecules. The bound VEGF molecules cannot activate VEGF receptors, so blood vessels can't grow or leak. There are no long-term results on safety and effectiveness of the use of intravitreal Avastin for neovascular AMD, but short-term data indicate that it may be of value. Intravitreal Avastin may lead to complete regression of neovascular formation. Clinically, data have indicated that there was a dramatic and rapid response to the injection, with complete resolution of the vascular leakage in most cases. Animal studies have suggested that Avastin was too large to cross the retina into the subretinal space [25]; however, other results [23] have confirmed the effects of intravitreal Avastin on choroidal neovascularization (CNV). One possibility is that this large molecule is able to cross the diseased retina more readily. Another possibility is that Avastin inhibits VEGF in the vitreous, the surface of the retina, or inside the retina, which may be enough to prevent further growth and leakage from the CNV. In a study of 32 patients, intravitreal injections of Avastin were associated with a rapid regression of retinal and iris NV secondary to PDR [24]. Another small uncontrolled study showed improvement of visual acuity and decreased retinal thickness after intravitreal injection of Avastin [26]. Yet another study showed that intravitreal Avastin injections were followed by reduction of fluorescein leakage from persistent active NV without loss of vision in patients with DR [27]. Finally, it is possible that the results of the animal studies may not apply to the human eye, and Avastin is able to cross the retina. There are several potential adverse effects associated with the systemic use of VEGF inhibitors, such as increased risk for thromboembolic events, hypertension, epistaxis, hemoptysis, proteinuria, delayed wound healing after surgery, and impaired reproductive function [25, 28]. Visual loss in the fellow eye may occur by inhibiting VEGF, which would cause regression of the choriocapillaris [29]. In one primate study, an intravitreal injection of Avastin was noted to cause occlusion of the choriocapillaris from thrombocytes and leucocytes and a reduction in choroidal capillary fenestration [30]. Apart from a low incidence of endophthalmitis associated with repeated intravitreal injections of anti-VEGF agents, no significant adverse effects have been noted clinically [31]. Fears that therapies blocking the action of all VEGF isoforms (Fig. 3) might have adverse effects have not been realized in practice [31].

The second "small molecule" of this category that target VEGF is Macugen (pegaptanib); an aptamer that binds specifically to the VEGF165 isomer and neutralizes the isoform's ability to bind to its cognate receptors VEGFR-1 and VEGFR-2 (Fig. 4). Aptamers are a new class of therapeutics macromolecules composed of chemically synthesized single-stranded nucleic acids, which maintain a highly specific three-dimensional conformation that allows binding with selective affinity to a molecular target in a manner similar to the binding of antibody to antigen. Previous investigations have demonstrated that blocking VEGF165 with Macugen was as effective as blocking all the isoforms in preventing pathological NV (Figs. 3, 4) [32]. Therefore, Macugen was the first aptamer to receive FDA approval for use in humans. In a phase II clinical trial, patients treated with intraocular injections of Macugen had better visual acuity outcomes, were more likely to show reduction in central retinal thickness and were deemed less likely to need additional therapy with photocoagulation at follow-up as compared with the sham-injected control subjects [33].

The third member of this group that specifically target VEGF is Lucentis (ranibizumab) (Fig. 4), which is another modified humanized MoAb fragment against all human VEGF [18] that is currently used clinically for ocular NV. Studies with patients showed that intraocular injections of Lucentis significantly reduced foveal thickness and improved visual acuity [34]. Although the previous drugs have shown very promising results, one setback is that they often need repeated delivery. All three agents; Avastin, Macugen and Lucentis are given by intravitreal injection and appear to be well tolerated. The lower molecular weight Lucentis is cleared more rapidly (3 days) [35] from the vitreous than the higher molecular weight Avastin (9.8 days) [36] and 10 days for pegaptamib. Although both Macugen and Lucentis have been shown in randomized controlled clinical trials (e.g., ANCHOR, MARINA, V.I.S.I.O.N.) to be effective in the control of CNV in AMD with a consequent improvement in vision [31], neither preparation has been used extensively in 


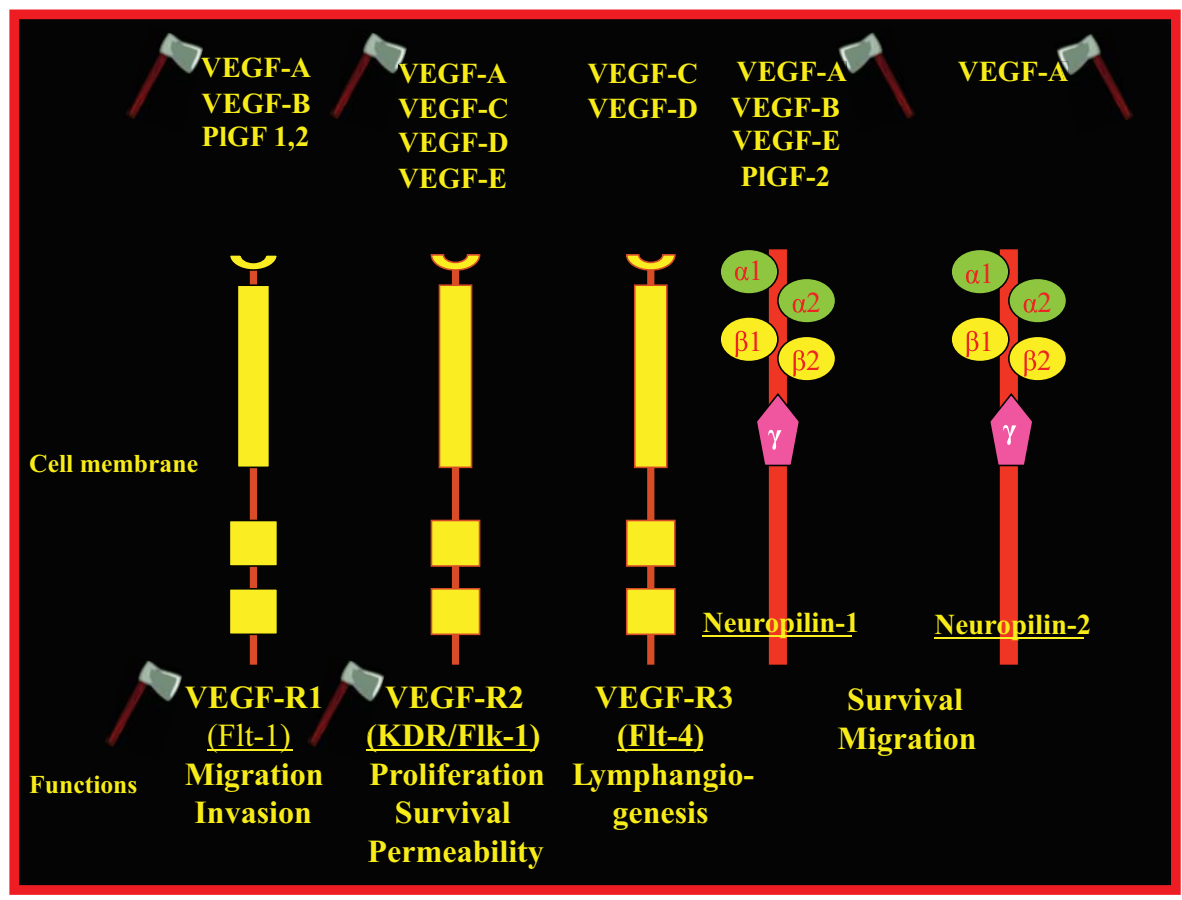

Fig. (3). VEGF Receptor and Ligands. VEGF receptors and related ligands include VEGFR-1 (Flt-1), VEGFR-2 (KDR/Flk-1), and VEGFR-3 (Flt-4), neuropilin-1, and neuropilin-2. The interaction of VEGFR with either neuropilin-1 (NRP-1) or heparin sulfate proteoglycan may facilitate the presentation and binding of VEGF to its receptor. These receptors have numerous immunoglobulin G-like extracellular domains and intracellular TK activity. There are several splice variants of VEGF, including VEGF 121, 145, 165, 189, and 206, with VEGF165 being the predominant form. Other members of the VEGF family include; VEGF-B, -C, and -D and PlGF. VEGF binds to VEGFR-1 and -2 and are involved in triggering angiogenesis. PlGF is localized to the placenta and binds only to VEGFR-1. VEGF-B also binds only to VEGFR-1 and appears to be involved in coronary vascularization and growth. VEGF-C and VEGF-D activate VEGFR-2 and -3 but not VEGF-1. VEGF-C is implicated in lymphangiogenesis.

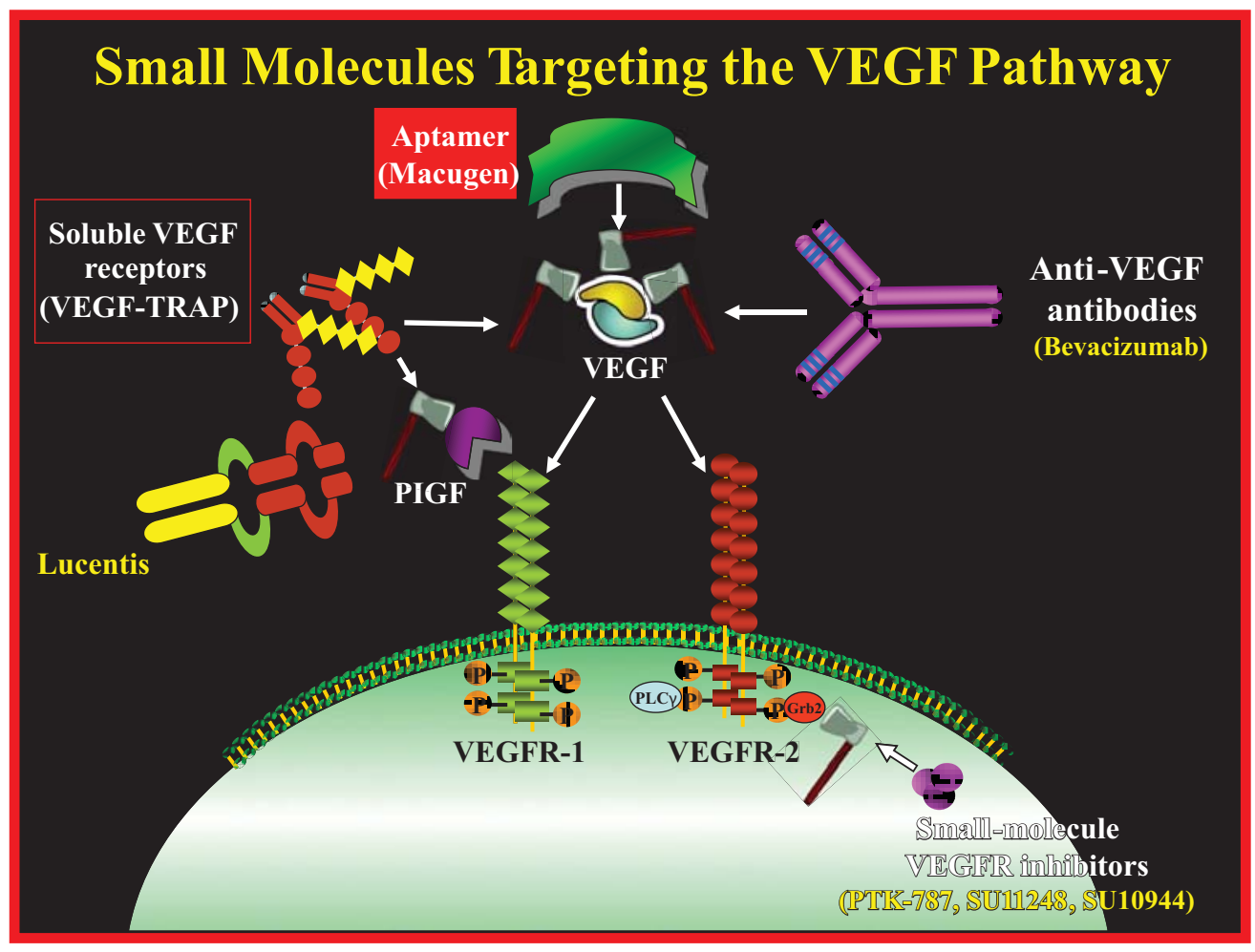

Fig. (4). Therapeutic Modalities To Target VEGF Signaling Pathway in Ocular Pathologies. Small molecules targets VEGF-signaling pathway by; (1) inhibiting the angiogenic factor VEGF; (2) Inhibition of VEGF-secretion; (3) Inactivation of VEGF; (4) Blockade of VEGF receptors on ocular ECs; (4) Inhibition of postsynaptic VEGF induced cell activation. 
the management of macular edema from inner blood-retinal barrier (iBRB) breakdown. FDA has approved formulations for AMD include Macugen and Lucentis, both intravitreous injections requiring repeated injections. However, Avastin is approved for systemic use in certain metastatic cancers and has been effectively used as an intravenous or intravitreous agent for human neovascular AMD [23, 28].

A systemically delivered, modified VEGF receptor; Aflibercept (VEGF-TRAP) is another small molecule "fusion protein", which is specifically designed to bind all forms of VEGF-A and placental growth factor (PLGF); which are both involved in the abnormal growth of new blood vessels. Counteracting the effects of VEGF-A and PLGF may provide a significant therapeutic effect in patients suffering from these disorders (Fig. 4). In addition to AMD; Regeneron and Bayer HealthCare extended the development program for VEGF Trap-Eye to include CRVO. Recent data from the Phase I study of intravenous VEGF Trap (aflibercept) in patient with advanced solid studies have indicated that IV VEGF Trap was well tolerated at the dose levels tested. In addition, pharmacodynamic and pharmacokinetic markers were indicative of VEGF blockade [37].

Delivery of a small interfering RNA (Ribonucleic Acid Interference) (RNAi) is a gene-silencing mechanism utilized by cells to specifically target the expression of genes corresponding to a double-stranded RNA or siRNA that has been introduced into the cell and to reduce the levels of the specific protein product in the targeted cells. This method could be used in vitro and in vivo $[38,39]$. Therefore, RNA interference has potential for application to studies of retinal biology and for the treatment of a variety of retinal diseases, including that involving abnormal blood vessel growth [40]. In the case of neovascular AMD, investigators have focused on downregulating VEGF and its receptor [40, 41]. In addition, Adenovirus vector has been used as the delivery vehicle for the siRNA targeting VEGF. This model overcomes the main hindrance to the therapeutic potential of siRNA, its limited stability, and the need to specifically deliver it to the pathologic cells. Furthermore, previous data have shown that VEGF messenger RNA (mRNA) silencing of $>90 \%$ in a human RPE cell line and over $80 \%$ reduction in the size of CNV in a murine model of neovascular AMD by adenovirus-mediated subretinal delivery of siRNA targeting VEGF [41]. Interestingly, previous investigations have shown that siRNAs 21-nucleotide or longer dsRNAs were antiangiogenic and were able to suppress CNV in mice regardless of the sequence they are targeting via their interaction with a cell surface receptor called toll-like receptor 3 [42]. Their study has shown that two investigational siRNAs in clinical trials owe their antiangiogenic effect in mice not to target knockdown but to TLR3 activation. These findings have supported investigations of non-targeted dsRNAs as generic anti-CNV agents as effective as anti-VEGFA antibodies, while avoiding potential neurotoxicity resulting from chronic administration of the latter. In addition, previous studies have used a vector-based siRNA expression system, which overcomes the limitations of transience and high cost in synthetic siRNAs, to specifically inhibit $\mathrm{VEGF}_{165}$ expression in the murine model of proliferative retinopathy [43]. Their data confirmed the potential $\mathrm{VEGF}_{165}$ inhibitors for the treatment of ocular angiogenesis. Previously, Acuity Pharmaceuticals reported that in a primate disease model, its lead product, Cand5 (bevasiranib), significantly inhibits both NV and vascular leakage that lead to vision loss in wet AMD. Cand5 is a siRNA that targets VEGF. The study data demonstrated that a single dose of Cand5 safely and significantly reduced both $\mathrm{NV}$ and vessel leakage, in a dosedependent manner for more than five weeks. At the highest dose used in the study Cand5 reduced the incidence of clinically significant vascular leakage to zero by week three and for the duration of the study, and at day $35 \mathrm{NV}$ was inhibited by greater than $65 \%$ in the high dose group. No adverse effects were observed [44]. Cand5 has entered a Phase III trial for the treatment of wet AMD. The study assess whether Cand5 administered every 8 or 12 weeks is safe and has equivalent efficacy in preventing vision loss as Lucentis administered every 4 weeks. In a Phase II trial, Cand5 was demonstrated to be safe and well tolerated and revealed benefits against several end points, including near vision and lesion size. Furthermore, AGN211745 (formerly Sirna-027 is in development for wet AMD by Allergan, has reached Phase II; in an earlier trial, it was reported to improve or stabilize visual acuity in a subset of patients. A third siRNA in wet AMD, RTP801i (Quark Pharmaceuticals), entered into Phase I clinical trials.

\section{INHIBITORS OF THE TYROSINE KINASE SIGNA- LING PATHWAYS}

Recent investigations in tumor biology have focused on multi-kinase inhibitors, such as Sutent, (PTK787) (Fig. 4) [45], and Axitinib (AG013736) to block angiogenesis [46]. Recently, Pfizer announced that the Phase III AXIS 1032 trial, studying axitinib, (AG013736) [47], in previously treated patients with metastatic renal cell carcinoma, has met its primary endpoint, demonstrating that axitinib significantly extended progression-free survival when compared to sorafenib (Nexavar, Bayer Healthcare/Onyx Pharmaceuticals), in the study population. Consistent with previous analyses, axitinib demonstrated a generally manageable safety profile in this study. Several studies have utilized two similar compounds, AG013711 and AG013764, which are small molecule inhibitors of VEGFR-1, VEGFR-2 and related receptor tyrosine kinases (RTK) such as plateletderived growth factor receptor (PDGFR) [48]. Combined activity against VEGF and PDGF signaling transduction is beneficial since both growth factors are involved in angiogenesis (Fig. 5). VEGF induces endothelial cell proliferation, migration, tube formation, increases vascular permeability, leukocyte trafficking, and is critical in ensuring the survival of proliferating ECs. PDGF induces pericyte recruitment and supports vascular maturation. Inhibitors of PDGFRs have been shown to produce pericyte loosening or detachment from ECs of tumor vessels [49]. In addition, blood vessels lacking pericytes are more susceptible to VEGF deprivation. Therefore, inhibitors targeting both VEGFR and PDGFR can contribute to the regression of actively proliferating ECs in tumors [46] and in multiple models of ocular NV [50]. Both compounds; AG013736 and AG013958 target both VEGF and PDGF pathways and have the potential to induce regression of $\mathrm{CNV}$ beyond what Macugen or Lucentis can accomplish individually. Previous data have shown that Sub-Tenon administration of AG- 


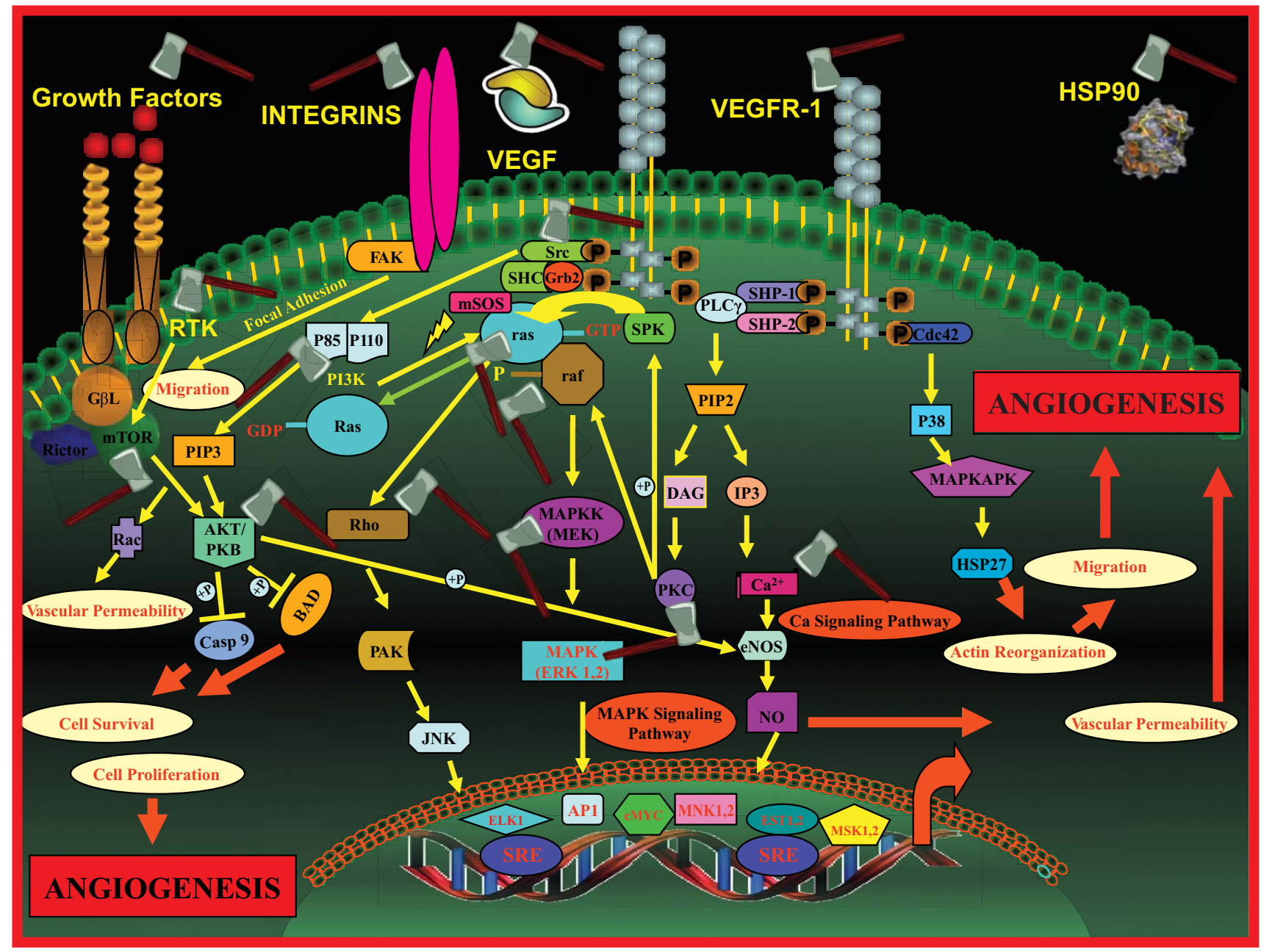

Fig. (5). Targeting the VEGF Signaling Pathway with Various Small Molecules. VEGF regulates several endothelial cell functions, including proliferation, differentiation, permeability, vascular tone, and the production of vasoactive molecules. Upon ligand binding, the receptor tyrosines are phosphorylated, allowing the receptor to associate with and activate a range of signaling molecules, including PI3K, Shc, Grb2, and the phosphatases SHP-1 and SHP-2. VEGF receptor activation can induce activation of the MAPK cascade via Raf stimulation leading to gene expression and cell proliferation, activation of PI3K leading to PKB activation and cell survival, activation of PLC- $\gamma$ leading to cell proliferation, vasopermeability, and angiogenesis. There is a cross-talk between Integrins and tyrosin kinase.

013958 (Pfizer, Inc.) in 21 patients with subfoveal CNV associated with AMD resulted in minimal levels of systemic exposure, which was similar to levels found in 13 cynomolgus monkeys dosed with the same compound [51]. Several studies have indicated that intravitreal injections of AG013764 or AG013711 reduced the level of CNV by approximately $60 \%$ compared to control [52].

The discovery of a multiple VEGFR inhibitors representing a variety of pharmacophores offers the opportunity to generate new molecules with increased potency or improved pharmaceutical properties by rational design based on cocrystals with VEGFR-2. Several investigations have revealed that 3-[5-methyl-2-(2-oxo-1, 2dihydro-indol-3-ylidenemethyl)-1H-pyrrol-3-yl]-proprionic acid (SU10944) is an inhibitor of VEGFR-2. SU10944 can be administered in vivo by the oral route and achieves sufficient exposure to inhibit nearly all VEGF-stimulated $\mathrm{NV}$ and vascular permeability. In addition, a compound of this nature will be valuable in delineating the role of VEGF in various forms of pathological angiogenesis where multiple kinases may play contributing roles. Previous studies have demonstrated that SU10944 inhibited VEGF-induced receptor autophosphorylation as well as downstream signaling [53]. Furthermore, SU10944 exhibited potent inhibitory activity against VEGFR-1; weak activity against other related subgroup members, including stem cell factor receptor (SCFR), PDGFR, and FGFR-1; and no detectable activity against other protein tyrosine kinases such as epidermal growth factor receptor (EGFR), Src, and hepatocyte growth factor receptor (HGFR). In cellular assays, the selectivity for SU10944 to inhibit VEGFR is maintained compared with other tyrosine kinases. Oral administration, SU10944 gave a clear dose response in the corneal micropocket model. Moreover, SU10944 potently inhibited VEGF-induced vascular permeability.

Specific multi-targeted RTK inhibitors have demonstrated broad and potent anti-angiogenic activities by targeting several angiogenic-signaling pathways. Sutent 
(SU11248) is a small, orally bioavailable molecule that has been identified as a low-nanomolar inhibitor of the angiogenic receptor tyrosine kinases; PDGFR- $\alpha$, and PDGFR- $\beta$, as well as VEGFR-1 and -2, KIT (stem cell factor receptor), and FLT3 (Fms-like tyrosine kinase-3 receptor) (Fig. 4). This agent has demonstrated anti-angiogenic and/or antitumor activity in preclinical studies, including tumor regression in murine models of human epidermal (A431), colon (Colo205 and HT-29), lung (NCI-H226 and H460), breast (MDA-MB-435), prostate (PC3-3M-luc), and renal (786-O) cancers, and suppression or delay in growth of many other tumor models, including subcutaneous C6, GL261, and SF763T glioma xenografts [54]. More recently, SU11248 has demonstrated efficacy with acceptable tolerability in a phase III clinical trial involving patients with gastrointestinal stromal tumor and two phase II trials involving patients with metastatic renal cell carcinoma [45], and it is under-going earlier stage clinical trials for various other cancers, including breast and non-small-cell lung tumors. Promising SU11248 clinical results to date support the hypothesis that targeting VEGF- and PDGFR-mediated signaling is an effective approach in the treatment of human cancers. Furthermore, SU11248 effectively blocked hypoxia-induced retinal NV in zebrafish, while the formation of new vascular branches was virtually totally inhibited [55].

To date, most clinical trials of anti-angiogenic therapy for ocular disease have evaluated agents that specifically bind VEGF, thus preventing VEGF-receptor activation. ZM323881 (5-[7-(benzyloxy) quinazolin-4-yl] amino]-4fluoro-2-methylphenol) is a selective inhibitor of human VEGFR-2/KDR activity [56]. Data have indicated that ZM323881 selectively inhibits VEGFR-2 over VEGFR-1 and a range of other receptor tyrosine kinases such as PDGFR $\beta$, FGFR1, EGFR and erythroblastic leukemia viral oncogene homolog 2 (erbB2) [57]. Angiopoietins and Tie2 receptor were recently identified as an endothelial cellspecific ligand-receptor system that is critical for vascular development and postnatal pathologic angiogenesis by mediating vascular integrity. Tie2 and angiopoietins are upregulated in the retina from patients with ischemic retinal disorders [58]. Recent studies demonstrated that Tie2 plays a key role in mediating both retinopathy and CNV. Immunohistochemistry with a monoclonal antibody to human Tie2 showed a prominent expression of Tie 2 around and within the base of newly formed blood vessels of retinal and choroidal neovascular lesions. Several small-molecule Tie2 inhibitors have been identified. These molecules have blocked Ang1-induced Tie2 autophosphorylation and downstream signaling. Further optimization of these molecules has yielded improved selectivity, aqueous solubility, microsomal stability and cytochrome P450 profile for one of the compounds. Some of these compounds have inhibited endothelial cell tube formation. Intravitreal injection of sTie2-Fc, soluble Flt-1 fusion protein (sFlt-1$\mathrm{Fc}$ ), and both chimeric proteins suppressed retinal angiogenesis in a murine model of retinal ischemia in the order of sTie2-Fc $<$ sFlt-1-Fc $<$ sTie2-Fc+sFlt-1-Fc [58]. In addition, systemic soluble Tie2 expression inhibited corneal NV [59].

Phosphatidylinositol 3-kinase (PI3 kinase) inhibition is also considered as an attractive pathway to modulate the development of angiogenesis in the eye. One example is
LY294002, which shows dose-dependent anti-angiogenic effects, without perturbing existing vessels. The antiangiogenic effect of LY294002 can be phenocopied using an inhibitor to AKT, which itself is known to act downstream of PI3K. In addition, intraocular administration of LY294002 selectively inhibits angiogenesis in the eye but does not diminish visual function [60]. Moreover, the inhibition of the splicing factor kinase 1/2 (SRPK1/2) via a small molecule SRPIN340 has previously been shown to block the RNAbinding splice factor ASF/SF2 phosphorylation, while the inhibition of distal splice site selection is brought about by the Cdc2-like kinase (Clk) inhibitor TG003. TG003, an inhibitor of the Clk family of kinases implicated in splicing control by phosphorylating splicing factors, inhibited TGF$\beta 1$ induced VEGF ${ }_{x x x} b$ expression. Data have indicated that TGF- $\beta 1$ stimulates the synthesis of VEGF ${ }_{\mathrm{xxx}} \mathrm{b}$ isoforms through p38 MAPK and Clk kinases [61]. Previous studies have indicated that intravitreous injection of SRPIN340 significantly reduced leakage of lesions in fluorescein angiography and significantly inhibited CNV in a mouse model [62]. In addition, several scientific investigations have utilized the concepts of targeting VEGF-receptor family and the inhibition of the fibroblast growth factor receptor (FGFR) and PDGFR tyrosine kinases as an alternative therapeutic modality to target vascular formation. Several groups have previously shown that JNJ-17029259 interferes with VEGF-stimulated signal transduction in human umbilical vein endothelial cells (HUVECs) cells including proliferation, VEGF-R2 receptor phosphorylation and MAP kinase activation [63]. These studies have shown that JNJ17029259 significantly inhibited normal development of the eye in the chick embryo in a dose-responsive manner, presumably by interfering with formation of the blood supply to the eye. In the corneal micropocket assay of retinopathy in both rabbits and mice, oral administration of JNJ-17029259 blocked the FGF-induced growth of new vessels in the eye. In these models, both vessel length and vessel area were significantly reduced in a dose responsive manner. These results demonstrate the utility of VEGF receptor kinase inhibitors in treatment of ophthalmic neovascular disorders [64]. Another small molecule inhibitor of PI3 kinase is Wortmannin, which blocks the catalytic activity of PI3-kinase without affecting the upstream signaling events. Previous data have shown that Wortmannin can inhibit proliferation and migration of ECs induced by Müller cell conditioned medium (HGMCM) [65].

Downstream signals from VEGF; like the small GTPase, Ras homolog gene family, member A (RhoA) have been targeted (Fig. 5). H-1152 is a cell permeable, highly specific, potent and ATP-competitive inhibitor of Rho kinase (ROCK). In addition, H-1152 inhibits the phosphorylation of myristoylated alanine-rich C-kinase substrate (MARCKS) in cells stimulated by lysophosphatidic acid, as well as it inhibits the prostaglandin E receptor EP3 subtype-stimulated NO formation. Several groups have utilized the mouse model of OIR, ROCK I/II inhibition by H-1152, which resulted in increased angiogenesis [66]. This enhanced angiogenesis, however, was completely blocked by the VEGF-receptor antagonist Vatalanib (PTK787)/ZK222584. Loss-of-function experiments in ECs revealed that inhibition of ROCK I/II using the pharmacological inhibitor $\mathrm{H}-1152$ and ROCK I/II-specific small-interfering RNAs resulted in a 
rise of VEGF-driven sprouting angiogenesis. Other investigations have recently indicated that $\mathrm{H}-1152$ plays a major role in promoting cell survival and reducing reactive gliosis in the rodent retina via the attenuation of glial cell reactivity [67].

Several inhibitors of the kinase activity of VEGF receptors, PDGF receptors, and c-kit have been shown to completely inhibit retinal NV. Studies from Campochiaro's lab have indicated that PTK787 completely inhibited retinal $\mathrm{NV}$ in murine OIR and partially inhibited retinal vascularization during development [68]. Previous studies have indicated that tyrosine kinase inhibitors are promising substances not only in cancer therapy, but also in the treatment of ischemic retinopathies that are mediated by VEGF [69]. Furthermore, TG100572; a topically applied small molecule VEGFR2/Src kinase inhibitor permeates the cornea and is present and active in the retina [70]. This small molecule evolved through a structure-based drug design approach to potent Src inhibitors of the benzotriazine class [71]. TG100572 potently inhibits a number of tyrosine kinases responsible for mediating vascular leak and/or angiogenesis. TG100572 was shown to stop NV and to decrease inflammation, both of which are characteristics of wet macular degeneration. TargeGen, Inc. have demonstrated that topical (eye drop) administration of the prodrug, TG100801, may be effective for the treatment of retinal disease and may also be used in combination with approved products. TG100801 converts to the active drug TG100572 as it penetrates the eye. TG100801 demonstrated the ability to reduce VEGF-mediated retinal leakage, angiogenesis and inflammation after topical instillation. Data have suggested that TG100801 is well tolerated in humans at the low and high doses tested when applied topically twice daily for 14 days.

Certain small molecules have exhibited the ability to target the signaling pathways of several kinases. PTK787 is a great example, which targets the kinase activity of several isoforms of PKC (Fig. 5), VEGF receptors, PDGF receptors, and c-kit, but not of receptors of several other growth factors that have been tested [72] (Fig. 4). In either rho/PDGF-B or rho/PDGF-A mice, oral administration of PKC412 or PTK787, but not SU1498 or imatinib mesylate, significantly reduced ERM formation. PKC412 reduced the incidence of severe retinal detachments in both models and PTK787 did so in homozygous rho/PDGF-A mice [73]. Furthermore, PKC412 (protein kinase $\mathrm{C}[\mathrm{PKC}]$ inhibitor) decreased leakage caused by prostaglandins, which implicate PKC in retinal vascular leakage caused by prostaglandins.

Sorafenib is a multikinase inhibitor, which blocks the action of VEGF, PDGF and the MAP kinase pathway. Sorafenib blocks the action of receptor tyrosine kinases, a class of molecules that transmit the signal that a receptor has been activated from the receptor to the nucleus of the cell. Sorafenib is a drug that is traditionally used to treat cancer, has shown promise as a neovascular AMD treatment. This study investigated the effects of sorafenib on light-induced overexpression of growth factors in human RPE cells. Human RPE cells were exposed to white light and incubated with sorafenib. Light exposure decreased cell viability and increased expression and secretion of VEGF, PDGF and
PlGF. These light-induced effects were significantly reduced when cells were treated with sorafenib. The investigators conclude that sorafenib has promising properties as a potential antiangiogenic treatment for AMD [74]. Another small-molecule kinase inhibitor is pazopanib, which blocks VEGFR1, VEGFR2, and VEGFR3. Furthermore, pazopanib also has substantial activity directed against $\operatorname{PDGFR} \alpha$, PDGFR $\beta$, c-Kit, FGFR1, FGFR3, and c-fms. Therefore, pazopanib has an interesting inhibitory profile with regard to potential effects in angiogenic diseases. Previous data investigated the effects of pazopanib in mouse models of subretinal NV [75]. Data indicated that orally administered pazopanib has good bioavailability to the retina/choroid and strongly suppresses CNV in mice. Treatment with pazopanib after $\mathrm{CNV}$ is established causes dose-dependent regression of CNV.

Mammalian target of rapamycin (mTOR) is a protein kinase that controls cell growth, proliferation, and survival (Fig. 6). mTOR signaling is often upregulated in cancer and there is great interest in developing drugs that target this enzyme. Rapamycin and its analogs bind to a domain separate from the catalytic site to block a subset of mTOR functions. These drugs are selective for mTOR and are already in clinical use for treating cancers, but they could potentially activate an mTOR-dependent survival pathway that could lead to treatment failure. By contrast, small molecules that compete with ATP in the catalytic site would inhibit all of the kinase-dependent functions of mTOR without activating the survival pathway. Rapamycin inhibits the translation and activity of HIF-1 $\alpha$, a stress-activated protein that regulates numerous survival proteins involved in angiogenesis and hyperpermeability [76]. In fact, HIF- $1 \alpha$ is a potent stimulator of VEGF, and its inhibition affects VEGF at the production level and at the receptor level [77]. Moreover, several non-selective mTOR kinase inhibitors have been described and here we review their chemical and cellular properties. Further development of selective mTOR kinase inhibitors holds the promise of yielding potent anticancer drugs with a novel mechanism of action. Furthermore, previous investigations have indicated that Rapamycin significantly reduced the extent of NV in both the CNV and the ROP model [78]. In addition, Rapamycin suppressed corneal NV, possibly by inhibiting proinflammatory cytokines [79]. In a recent randomized pilot study of systemic immunosuppression in the treatment of AMD with $\mathrm{CNV}$; patients were randomized to 1 of 3 systemic arms immunosuppressive agents (daclizumab, rapamycin, or infliximab) for 6 months plus intraocular antiVEGF therapy if indicated, compared with a group who received only anti-VEGF therapy if indicated. Thirteen patients were randomized; comparing anti-VEGF injections before and during the study. Results indicated that there was a decrease in the number of injections from 0.73 injections per month to 0.42 for daclizumab and from 0.67 to 0.34 for sirolimus, while no apparent decrease was seen for either infliximab or observation. Visual acuities were maintained in all groups. Preliminary data have suggested that some immunosuppressive agents given systemically can alter the clinical course of the wet form of the disease and support the notion that more definitive clinical trials of immune mediation of AMD are indicated [80]. 


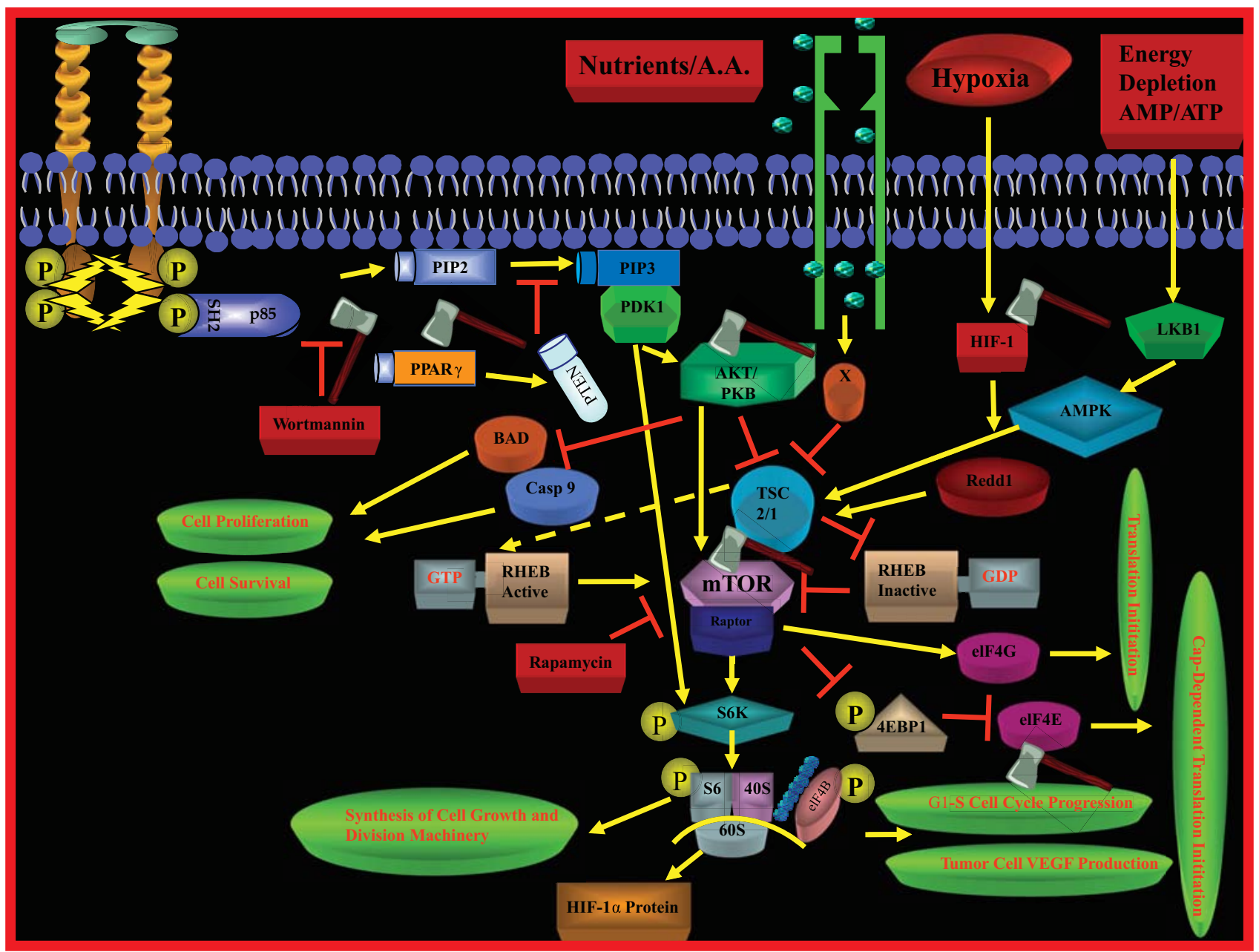

Fig. (6). Schematic Illustration of Insulin/IGF-I and Other Factors that Regulate mTOR Signaling Pathway. Insulin/IGF-I stimulates activation of the PI3K-PDK1 pathway, leading to phosphorylation of p70S6K in the activation loop (Thr229). Nutrients, such as amino acids and glucose, regulate the mTOR signaling pathway through an uncharacterized mechanism, and protein X represents an unknown molecule that senses the amount of amino acids in the cell and inhibits the TSC complex or activates the mTOR pathway somewhere between the TSC complex and mTOR complex, but most likely involve activating the small G protein Rheb. Activation of the PI3K-PDK1-Akt pathway may indirectly enhance p70S6K phosphorylation at the HM site via inhibition of the tuberous sclerosis protein complexes TSC1 and/or TSC2, which are inhibitors of the mTOR signaling pathway.

MacuSight, Inc. in collaboration with the Retinal Consultants of Arizona/Spectra Eye Institute in Sun City, AZ, have completed two phase 1 studies; one for DME, and one for wet AMD. The randomized, open-label, doseescalation study ran in parallel with a study of the same drug for treatment of DR. Perceiva (a proprietary ocular formulation of sirolimus) is injected either subconjunctivally or intravitreally for up to three months. Developers have indicated that sirolimus is different from other antiangiogenic drugs in that it is "a highly-potent, broad-acting compound that has demonstrated the ability to combat disease through multiple mechanisms of action including immunosuppressive, anti-angiogenic, anti-migratory, antiproliferative, anti-fibrotic and anti-permeability activity," and that it may, therefore, serve as a potentially highlyefficacious therapeutic for a wide range of ocular diseases and conditions. Investigators found that the drug was welltolerated at all doses for both administration methods tested, with no reported IOP elevations, inflammatory effects or indications of cataract progression. There were no doselimiting toxicities, ocular inflammation, or increase in intraocular pressure. In addition, investigators from both studies noted improvements in visual acuity and reductions in retinal thickness with observed beneficial anatomical changes following a single administration of. These findings were consistent across both routes of administration. These promising results for Perceiva delivered with subconjunctival injection provide the first evidence for the potential of treating retinal disease without direct injection into the back of the eye. The majority of ocular adverse events were related to the injection procedure were mostly mild and transient in nature. Systemic exposure was negligible and insufficient for systemic immunosuppression. As an mTOR inhibitor, sirolimus possesses a broad spectrum of therapeutic action which MacuSight recognized as potentially relevant to the treatment of ocular diseases, including the inhibition of inflammation, angiogenesis, vascular permeability, proliferation and fibrosis. Designed 
for minimally invasive, sustained, local administration, Perceiva may offer more comfort to patients and more convenience to physicians, while minimizing the risk of complications and adverse events. In 2010, Perceiva is being advanced in a broad Phase 2 clinical program across multiple large ocular indications including diabetic DME, wet AMD, uveitis and dry AMD. Additionally, as part of this Phase 2 program, the company is using Perceiva to evaluate the potential role for sirolimus in the treatment of dry eye syndrome (DES).

Retinal NV has been targeted at the molecular chaperone level. Investigators have used antagonists to the heat shock protein 90 (Hsp90) [81] (Fig. 5). The Geldanamycin analog, 17-allylamino-17-desmethoxygeldanamycin (17-AAG), is now in Phase I clinical trial at the NCI and several other sites. This drug represents a class of natural products known as benzoquinone ansamycins, which also contains herbimycin $\mathrm{A}$ and macbecin. Benzoquinone ansamycins are characterized by linkage of a quinone moiety to a planar macrocyclic ansa-bridge structure. Although these drugs were previously thought to be tyrosine kinase inhibitors, the mechanism of action of some benzoquinone ansamycins, including Geldanamycin and 17-AAG, must now be reevaluated following their demonstrated ability to specifically bind to and antagonize the function of the chaperone protein heat shock protein 90 (Hsp90). The ansamycin antibiotic GA and its modified derivative 17AAG bind to a conserved pocket in the Hsp90 protein and inhibit its function [82]. 17-AAG inhibits the Ras/Raf/MEK and PI3-Kinase signaling pathways and down-regulates VEGF expression (Fig. 5). Previously, data have demonstrated that an IP injection of 17-AAG was able to reduce angioproliferative retinopathy in a mouse model for OIR [83]. Furthermore, they have indicated that the mechanism does not involve a direct or indirect reduction of the VEGF mRNA level, but acts downstream of the VEGF pathway. Thus, 17-AAG probably does not work by PI-3 kinase inhibition but via the Ras/Raf/MEK pathway (Fig. 5).

\section{INHIBITORS OF THE CELL CYCLE}

Blocking the progression of the cell cycle has been investigated by several research groups as an ideal venue to target retinal NV. TNP-470, a synthetic analog of fumagillin, has been undergoing clinical trials for treating a variety of cancers. TNP-470 has been shown to block endothelial cell cycle progression in the late G1 phase. Although the direct molecular target for TNP-470 has been identified as the type 2 methionine aminopeptidase (MetAP2). Studies have reported that treatment of endothelial and other drugsensitive cell types leads to the activation of the p53 pathway, causing an accumulation of the G1 cyclindependent kinase inhibitor p21WAF1/CIP1 [84]. These results shed light on the mechanism of cell cycle inhibition by TNP-470 and suggest an alternative method of activating p53 in ECs to halt angiogenesis and tumor progression. Several studies have demonstrated that TNP-470 inhibits the growth and the capillary-like tube formation of ECs more sensitively than other types of cells [85]. Furthermore, Studies evaluated the efficacy of the conjugate TNP-470PVA in vivo, where it was shown to inhibit CNV in rabbits [86]. Their studies have also demonstrated that TNP-470PVA inhibited the growth of HUVECs in a biphasic manner similar to that of TNP-470. On the other hand, the bovine retinal pigment epithelial cells (BRPECs) exhibited less sensitivity to TNP-470-PVA than did the HUVECs, which suggested that TNP-470-PVA preserves the original bioactivity of TNP-470 and that, if this relationship between the two types of cells corresponds to that between choroidal ECs and RPE cells, this conjugate may inhibit the growth of ECs and produce less interference in the proliferation of RPE cells. These studies have suggested that targeted delivery of TNP-470-PVA may have potential as a treatment modality for $\mathrm{CNV}$.

Other small molecules that induce cell cycle arrest have been investigated in various models of ocular pathologies. IMS2186 is an anti-CNV drug in which its mechanism of action is proposed to be the arrest of the cell cycle at G2 phase, and the inhibition of prostaglandin E2 (PGE2) and TNF- $\alpha$ production; the latter contributing to antiinflammatory and anti-angiogenic effects [87]. Therefore, IMS2186 acts more upstream of the angiogenesis, rather than simply blocking the VEGF. Furthermore, IMS2186 has inhibitory effects in vitro, on not only angiogenesis, but also on the mobilization of macrophages and the proliferation of fibroblasts and other cell types.

\section{INHIBITORS OF THE BINDING SITES / RECEPTORS}

The ability to target the binding sites/receptors both in vitro and in vivo by applying blocking antibodies, antisense oligonucleotides, or soluble receptor has heralded modulation of growth factors as the way forward in treating PDR. Studies have shown that the heparin analog 5-amino-2naphthalenesulfonate (5-amino-2-NMS) reduced the mitogenic activity of fibroblasts. In addition, 5-Amino-2NMS blocked the heparin-binding site of FGF1 or FGF2 and thus hampered the interaction of FGF with its receptor at the cell membrane level. Furthermore, the induction of NV in mice by a subcutaneous FGF1-containing sponge was inhibited by the intraperitoneal injection of 5-amino-2-NMS [88]. The effect of (5-amino-2-NMS) on retinal NV was investigated in the OIR mouse model [89]. Data have indicated that a single intravitreal injection of 5-amino-2NMS reduces significantly angioproliferative changes compared to the contralateral control.

\section{INHIBITORS OF THE CALCIUM-ENTRY}

A number of anti-angiogenic strategies work through mechanisms distinct from those described above. CAI (betahydroxypropyl cyclodextrin [ $\beta \mathrm{HPCD}]$ ) is an inhibitor of calcium influx, which is currently in phase I studies in combination with Paclitaxel against solid tumors (Fig. 5). In vivo studies have demonstrated that CAI treatment reduced choroidal neovascular lesion volume. These studies have shown that intravitreal suspension CAI was highly effective in the CNV model, and possesses an ocular pharmacokinetic profile that may be superior to the standard 4-6 week administration interval and was well tolerated in the rat based on both anatomic and physiologic testing [90].

\section{PEROXISOME PROLIFERATOR-ACTIVATED REC- EPTOR Г (PPARГ) PATHWAY TARGETING}

Peroxisome proliferator-activated receptors (PPARs) are members of the steroid receptor superfamily and, as such, are ligand-activated transcription factors. PPAR $\gamma$ is a nuclear 
receptor that functions as a transcription factor to mediate ligand-dependent transcriptional regulation. PPARs signaling pathway regulates cell proliferation, survival, synthesis of cell growth and division machinery, G1-S cell cycle progression, and tumor cell VEGF production (Fig. 6). Several studies have reported on the potent and novel inhibitory activity of PPAR $\gamma$ ligands on HUVEC differentiation into tube-like structures and proliferation in vitro, and the inhibition of EGF elicited angiogenesis in vivo (Fig. 6). These studies demonstrated that PPAR $\gamma$ is an important molecular target for the development of small molecule inhibitors of angiogenesis, which may be useful therapeutic agents in the treatment of cancer and other vasculoproliferative disorders. Activation of PPAR $\gamma$ by the naturally occurring ligand, 15-deoxy-D12,14-prostaglandin J2 (15d-PGJ2), or members of a new class of oral antidiabetic agents, e.g. BRL49653 and ciglitizone, has been linked to adipocyte differentiation, regulation of glucose homeostasis, inhibition of macrophage and monocyte activation, and inhibition of tumor cell proliferation. Data have indicated that activation of PPAR $\gamma$ by the specific ligands 15d-PGJ2, BRL49653, or ciglitizone, dosedependently suppresses HUVEC differentiation into tubelike structures in 3D collagen gels. Moreover, treatment of HUVEC with 15dPGJ2 also reduced mRNA levels of VEGF receptors 1 (Flt-1) and 2 (Flk/KDR) and urokinase plasminogen activator and increased plasminogen activator inhibitor-1 (PAI-1) mRNA [91]. Administration of 15dPGJ2 inhibited VEGF-induced angiogenesis in the rat cornea [91]. In addition, previous data have indicated that Thiazolidinediones (TZDs) inhibits experimental retinal NV with an effect that is primarily downstream of VEGF expression [92].

\section{TUBULIN-BINDING AGENTS}

Combretastatin A-4 (CA-4) is an anti-tumor agent, which binds specifically to the colchicine-binding site on tubulin, a key protein in the process of cell division. Both molecules (colchicine and combretastatin A-4) cause a decrease in elasticity, therefore preventing cell division. Studies from Campochiaro's lab have indicated that in rho/VEGF mice, daily intraperitoneal injections of CA-4-P starting at postnatal day (P) 7, the time of onset of transgene expression, resulted in a significant reduction in the number of neovascular lesions and total area of NV per retina at P21, compared with vehicle-injected mice. In mice with laserinduced rupture of Bruch's membrane, daily intraperitoneal injections of CA-4-P resulted in a significant reduction in the area of $\mathrm{CNV}$ at rupture sites compared with vehicle-injected mice. In mice with established CNV, daily intraperitoneal injections of CA-4-P for 1 week resulted in a significant reduction in $\mathrm{CNV}$ area at rupture sites compared with the baseline area before treatment or the area of CNV in vehicletreated mice. These studies have revealed that CA-4-P suppresses the development of VEGF-induced NV in the retina and both blocks development and promotes regression of CNV. Therefore, CA-4-P shows potential for both prevention and treatment of ocular NV [93].

\section{INHIBITORS OF INTEGRINS}

Integrin $\alpha 5 \beta 1$ is the only integrin expressed on the apical surface of RPE cells in the mammalian eye, where it controls the phagocytosis of photoreceptor outer segments [94, 95] and probably the adhesion of RPE cells to the retina [94] (Fig. 5). In contrast, integrins $\alpha v \beta 3$, $\alpha 6 \beta 1$, and $\alpha 3 \beta 1$ are expressed on the basal lateral membrane of RPE cells where they enable their attachment to Bruch's membrane [96]. Moreover, $\alpha 5 \beta 1$ was highly expressed on surgically excised proliferative membranes, and proliferating and migrating RPE cells in vitro, yet normal retinal tissues showed little $\alpha 5 \beta 1$ expression. Together, these findings suggest that no impairment of physiological RPE function is to be expected during pharmacological therapy that specifically targets $\alpha 5 \beta 1$. The integrin $\alpha 5 \beta 1$-fibronectin $(\alpha 5 \beta 1-\mathrm{FN})$ interaction is a promising target for the treatment of proliferative vitreoretinopathy (PVR) with the potential to inhibit multiple pathogenic pathways, including the intraretinal proliferation and migration of RPE cells, the proliferation of Müller cells, the inflammatory response and resulting fibrosis, and, most likely, the transdifferentiation of RPE cells, the activation of Müller cells, and the response after the contraction of epiretinal membranes. Among these pathogenic processes, the activated Müller cells [97] and transdifferentiated RPE cells [98] are proposed to be the most important triggers of PVR.

JSM6427; 3-2-\{1-alkyl-5-[(pyridin-2-ylamino)-methyl]pyrrolidin-3-yloxy $\}$-(acetylamino)-2-(alkylamino)-propionic acid, is a small molecule inhibitor of the $\alpha 5 \beta 1-\mathrm{FN}$ interaction [99], with good tissue penetration and stability in physiological buffers. Furthermore, JSM6427 is a competitive integrin inhibitor mimicking the natural integrin recognition motif Arg-Gly-Asp. It inhibits the integrin a5 $\beta 1$ fibronectin interaction [99]. JSM6427 has a selectivity at least 1,700 -fold greater for $\alpha 5 \beta 1$ than for other integrins expressed in normal RPE [100] and has been shown to result in a dose-dependent reduction in FN-mediated ERK-1/2 phosphorylation in the spontaneously arising retinal pigment epithelia cell line (ARPE-19) [101]. Furthermore, JSM6427 resulted in the inhibition of multiple $\alpha 5 \beta 1$-mediated effects in vitro and in vivo, suggesting that it may provide some therapeutic benefit in the treatment of PVR [53]. It has been shown that JSM6427 is a promising treatment for PVR, with data suggesting that inhibition of $\alpha 5 \beta 1$-fibronectin interactions addresses multiple pathways involving retinal pigment epithelial, glial, and inflammatory cells. Previous data have demonstrated that single intravitreal injections of JSM6427 are well tolerated in patients with neovascular AMD and may show early indications of biological activity [102]. The repeat dose cohorts have completed enrollment and are in early follow-up. In addition a sustained-release formulation is in development for the prevention as well as the treatment of neovascular AMD.

\section{INHIBITORS OF THE RENIN-ANGIOTENSIN SYS- TEM (RAS)}

The hypothesis that an ocular RAS is involved in the development of PDR is supported by evidence that all components of the RAS are present in the retina [103, 104] and that Ang II, the effector molecule of this system, is angiogenic [105]. The renin-angiotensin system is well known as a major controller of systemic blood pressure. Angiotensin II (Ang II), a final product of the system, has two cognate receptors: the angiotensin II type 1 receptor (AT1-R) and the angiotensin II type 2 receptor (AT2-R) 
[106]. Because major Ang II-related systemic functions are mediated by AT1-R signaling, its antagonist is widely used for the treatment of hypertension and cardiac diseases. In contrast, several reports have recently suggested that Ang II plays crucial roles in promoting tumor angiogenesis and cardiovascular remodeling through the proliferation of smooth muscle cells and the induction of various growth factors [107-110]. Blockade of Ang II signaling seems to be a useful strategy for the improvement of inflammationrelated diseases. AT1 receptor blockers as well as ACE inhibitors attenuated preretinal pathological angiogenesis when administered during retinal ischemia [108, 109, 111]; in addition, it reduced inflammation [111]. Furthermore, ACE inhibitors reduce OIR in mice when administered during the hyperoxic period and this is associated with downregulation of ET-1 [112].

Studies have shown the localization of renin to the macroglial Müller cell [103] making this the likely site for pathophysiological processes involving the retinal RAS. Data have suggested that retinal RAS plays an important role in the pathogenesis of NV in the ROP model [108]. This information provides a rationale for the use of agents that interrupt the RAS in the prevention of proliferative retinopathy related to retinal hypoxia and possibly ischemia. Furthermore, several reports have suggested that Ang II plays a key role in various inflammatory processes, including not only the expression of chemokines and adhesion molecules for the recruitment of inflammatory cells, but also the differentiation and proliferation of inflammatory cells, per se [113]. Hypertension is well known to be a worsening factor in PDR [114]. A recent report [115] has shown the increased levels of Ang II in the vitreous fluid of patients with proliferative diabetic retinopathy, although its role in pathogenesis remains undetermined. More work is needed to establish the validity of this therapeutic approach in visionthreatening ischemic retinopathies. It has been demonstrated that the AT1, but not AT2, antagonist partially, but significantly, reversed the increase in retinal vascular hyperpermeability. In addition, data have demonstrated that olmesartan medoxomil partially, but significantly, inhibited the retinal vascular hyperpermeability induced by hypoxia. In contrast, PD123319 did not show a significant effect. The VEGF and HIF-1alpha protein levels were significantly elevated in the OIR retina; however, there was no significant effect of olmesartan medoxomil on the expression of either protein [116]. Moreover, losartan (enalapril maleate), an angiotensin converting enzyme (ACE) inhibitor, prevents the synthesis of angiotensin II [117]. This compound is used to treat high blood pressure, heart and renal abnormalities [118]. In zebrafish, this compound is toxic at higher concentrations and causes embryonic lethality. At lower concentrations, it causes a widening of intraocular blood vessels, while vessel thickness in the trunk does not display this effect. To test whether losartan activity in zebrafish is mediated via the inhibition of ACE, certain groups have demonstrated that morpholino knockdown of the ACE gene had no apparent effect on the blood vessel morphology in the eye [119]. Recent data have revealed early blockade of the renin-angiotensin system with losartan (100 mg daily), losartan (20 mg daily), in patients with type 1 diabetes did not slow nephropathy progression but slowed the progression of retinopathy [120]. ACE inhibitors have been shown to suppress the progression of human DR to its proliferative (angiogenic) stage [121].

Olmesartan Medoxomil is another small molecule, which belong to the class of medicines called angiotensin II receptor antagonists to treat high blood pressure. Olmesartan blocks the vasoconstrictor effects of angiotensin II by selectively blocking the binding of angiotensin II to the AT1 receptor in vascular smooth muscle. Its action is, therefore, independent of the pathways for angiotensin II synthesis. Olmesartan has more than a 12,500-fold greater affinity for the AT1 receptor than for the AT2 receptor. A previous study has demonstrated that both the AT1 and AT2 receptor mRNA are upregulated in OIR rat retinas [122], suggesting that these receptors may be involved in the pathogenesis of the OIR. Unlike the angiotensin receptor antagonist losartan, olmesartan does not have an active metabolite or possess uricosuric effects. Blockade of the angiotensin II receptor inhibits the negative regulatory feedback of angiotensin II on renin secretion, but the resulting increased plasma renin activity and circulating angiotensin II levels do not overcome the effect of olmesartan on blood pressure. Since olmesartan medoxomil is now available clinically as an antihypertensive drug, olmesartan medoxomil might have a beneficial effect in treating ischemic retinal diseases, such as DME. Additionally, research investigations on neonatal transgenic (mRen-2)27 rats, which overexpressd renin in tissues, have indicated that ACE inhibitor lisinopril (Prinivil) and the angiotensin type 1 receptor antagonist losartan both increased retinal renin levels and prevented inner retinal blood vessel growth [108]. Furthermore, lisinopril reduced both retinal VEGF and its type 2 receptor mRNA in ROP rats, whereas losartan had no effect. It is predicted that agents that interrupt the renin-angiotensin system may play an important role as retinoprotective agents in various forms of proliferative retinopathy. Moreover, the hypothesis that an ocular RAS is involved in the development of PDR is supported by evidence that all components of the RAS are present in the retina $[103,104]$ and that Ang II, the effector molecule of this system, is angiogenic [105]. Previous studies have localized renin to the macroglial Müller cells, making this the likely site for pathophysiological processes involving the retinal RAS [103]. The Müller cell is also the site of synthesis of the potent angiogenic factor VEGF and its tyrosine kinase receptors [123]. There is evidence of an association between VEGF, the RAS, and retinal NV, because both VEGF and prorenin increase in the vitreous of patients with PDR [8] and Ang II increases VEGFR-2 receptor mRNA in retinal ECs [110].

Candesartan cilexetil (candesartan) is in a class of drugs called angiotensin receptor blockers which includes losartan. Candesartan blocks the ability of the chemical angiotensin II to raise the blood pressure by constricting or squeezing arteries and veins. This leads to a reduction in blood pressure. In addition, by reducing the pressure against which the heart must pump blood, candesartan reduces the work of the heart and is useful in patients with heart failure. A 5-year study of candesartan treatment in type 1 diabetes reduced the incidence of retinopathy by two or more steps in severity by $18 \%$ and, in a post hoc analysis, reduced the incidence of retinopathy by three-step progression by $35 \%$. In type I diabetes patients there was no effect on progression of established retinopathy. In contrast, in type II diabetes, 5 
years of candesartan treatment resulted in $34 \%$ regression of retinopathy. Most significantly, an overall significant change towards less-severe retinopathy was noted in both type I and II diabetes [124, 125].

\section{GROWTH HORMONE INHIBITORS}

Growth hormone (GH) may be involved in the development of ROP and DR (Fig. 5). The initial association between GH and DR came from studies in which pituitary ablation was linked to the remission of DR [126, 127]. In subsequent studies, DR was found to be approximately three times more prevalent in Type I diabetic patients who are $\mathrm{GH}$ sufficient than those who were GH deficient [126]. GH deficient dwarfs with diabetes were free of microvascular complications [128], and $\mathrm{GH}$ replacement therapy for patients with $\mathrm{GH}$ deficiency induced a diabetic-like retinopathy, which is attenuated after discontinuation of $\mathrm{GH}$ treatment [129]. In terms of ROP, Smith and colleagues reported that retinal $\mathrm{NV}$ is reduced in transgenic mice expressing a GH antagonist gene that were subjected to experimental ROP [130].

GH has indirect effects, which are mediated primarily by insulin-like growth factor-1 (IGF-1), a hormone that is secreted from the liver and other tissues in response to $\mathrm{GH}$. A majority of the growth promoting effects of $\mathrm{GH}$ is actually due to IGF-1 acting on its target cells. GH secretion is part of a negative feedback loop involving IGF-1; where high blood levels of IGF-1 lead to decreased secretion of GH not only by directly suppressing the somatotroph, but by stimulating release of somatostatin from the hypothalamus. The type 1 IGF receptor (IGF1R) is a transmembrane tyrosine kinase that is frequently overexpressed by tumors, and mediates proliferation and apoptosis protection. IGF signaling also influences hypoxia signaling, protease secretion, tumor cell motility and adhesion, and thus can affect the propensity for invasion and metastasis. Therefore, the IGF-1R is now an attractive anti-cancer treatment target. Design of specific IGF-1R inhibitors has been problematic due to close homology with the insulin receptor, but recently it has proved possible to design selective IGF-1R inhibitors. These compounds and IGF-1R antibodies are showing promise in preclinical models of human cancer, and several agents are now in early phase clinical trials. Both classes of agents affect insulin receptor signaling, either by direct kinase inhibition or antibody-induced insulin receptor downregulation. This effect may lead to clinical toxicity, but could be therapeutically beneficial in blocking signaling via variant insulin receptors capable of a mitogenic response to IGF-II. Specificity for IGF-1R targeting can be achieved by antisense and siRNA-mediated IGF-1R downregulation; these approaches have undoubted utility as research tools, and may in future generate nucleic-acid-based therapeutics. It will be important to use data from preclinical and early clinical trials to establish the molecular correlates of sensitivity to IGF-1R blockade, and the optimum means of combining this new approach with standard treatment modalities. Therapeutic strategies for DR included early approaches to block the actions of $\mathrm{GH}$ such as hypophysectomy and pituitary radiation [127], and more recently, the use of the $\mathrm{GH}$ receptor (GHr) antagonist, pegvisomant, or inhibiting the secretion of $\mathrm{GH}$ from the pituitary using somatostatin or its analogues such as octreotide [130-132]. Previous investigations have tested whether systemically delivered antisense oligonucleotide could inhibit NV in mice with oxygen induced retinopathy (OIR) [133]. They reported the design and optimization of a "5-10-5" 2'-O-(2-methoxy)ethyl (2' MOE) modified antisense oligonucleotide (ASO) directed to the mouse $\mathrm{GHr}$, which suppresses GHr mRNA levels in vitro and in vivo and reduces binding of $\mathrm{GH}$ to liver cells in normal mice [133]. Their approach described the effect of this ASO; ATL 227446 on retinal $\mathrm{NV}$ in a mouse model of ROP. It was concluded that treatment with the GHr ASO, ATL 227446, reduced pathological retinal $\mathrm{NV}$ in OIR to a greater extent than octreotide or control oligonucleotides [133]. Systemically delivered GHr ASO may be a potential treatment for ocular NV related disorders such as ROP and DR [133].

\section{INHIBITORS OF INFLAMMATION AND VASCULAR LEAKAGE}

Corticosteroids have a specific effect on reducing vascular permeability [134]. Steroids have anti-angiogenic, anti-inflammatory, anti-apoptotic, anti-proliferative and antiedematous activity [135]. Hypoxia induces an inflammatory response in the retina with increased levels of inflammatory cytokines and macrophage attractants. As corticosteroids are anti-inflammatory, the actions of corticosteroids in conditions of hypoxia induced inner blood-retinal barrier breakdown (iBRB) include both anti-inflammatory activity and vascular permeability. In many clinically important conditions including diabetic retinopathy, central or branch retinal vein occlusion (BRVO), and some respiratory diseases retinal hypoxia results in a breakdown in the blood retinal barrier (BRB) [136]. Disruption of the iBRB with increased vascular permeability causes vasogenic retinal edema and tissue damage, with consequent adverse effects upon vision. Factors such as enhanced production of VEGF, NO, oxidative stress and inflammation underlie the increased permeability of the iBRB and inhibition of these factors may be therapeutically beneficial. In the eye the effect of most steroids is short-lived, requiring repeated or continuous administration to maintain therapeutic effect. Recent studies have demonstrated the usefulness of intravitreal injection of triamcinolone acetonide (TCA) in the reduction of inflammation [137, 138], vascular permeability [138] fibrovascular proliferation [139], and macular thickening due to diffuse DME, at least in the short-term [139]. In rabbit animal models TCA inhibited VEGF-induced vascular leakage in a rabbit model of blood-retinal and blood-aqueous barrier breakdown [140]. The relatively insoluble steroid TCA has much more prolonged activity in the eye [141]. Although some doubt must be raised about the acceptance of visible remnants of vitreal TCA as an indicator of the activity of this steroid within the vitreous, it does seem to be the case that the retention time of TCA is much longer than is the case with other anti-VEGF intravitreal preparations used. Adverse effects of intravitreal TCA include elevated intraocular pressure and cataract formation [142]. The general conclusion from various studies is that TCA alone or in combination with other treatments improves bestcorrected visual acuity (BCVA) in DME and reduces central retinal thickness during the early few months after commencement of treatment and that the results may be 
better than with laser treatment at this time. In a report of long-term results, however [143], laser treatment was more effective and had fewer side effects than intravitreal TCA.

Another anti-inflammatory agent under this category is dexamethasone (DEX), which is a potent and effective glucocorticoid (GC) [9-fluoro-glucocorticoid] ocular agent that is topically applied in ocular conditions, such as keratitis, uveitis, and iritis [144]. However, the adverse effects of prolonged use of DEX include decreased aqueous humor outflow and increased intraocular pressure (IOP), which may cause the onset of secondary glaucoma. The exact molecular mechanism of glucocorticoid-induced glaucoma (GIG) is still elusive, but evidence points to excessive extracellular matrix (ECM) material aggregation within the outflow channels in trabecular meshwork (TM) tissues as a result of ECM degradation inhibition, which subsequently leads to increased outflow resistance [145]. GC-induced ocular hypertension shares some clinical features with primary open-angle glaucoma (POAG). Besides IOP elevation, both secondary and primary glaucoma have selective retinal ganglion cell death that causes visual field changes, nerve fiber layer defects, and eventual irreversible blindness [145]. Several studies have noted that the GC-induced changes in TM can partially reflect the pathological mechanisms of POAG [146]. Investigations into the molecular mechanisms of GIG may provide new insights into the pathology of POAG.

\section{INHIBITORS OF ANGIOGENESIS}

Tryptophanyl-tRNA synthetase (TrpRS) is an aminoacyltRNA synthetase and a smaller proteolytic product in which the entire $\mathrm{NH}_{2}$-terminal domain has been deleted. It is involved in protein synthesis and regulation of RNA transcription and translation and is an inhibitor of angiogenesis. Previous studies have investigated the angiostatic activity of T2-TrpRS [147]. Their data have revealed that unlike the $20-40 \%$ inhibition of $\mathrm{NV}$ demonstrated by other anti-angiogenic compounds, preclinical studies of TrpRS have revealed that in $70 \%$ of cases there was $100 \%$ inhibition. Another potential advantage of TrpRS fragments is that they represent naturally occurring and, therefore, they could avoid the problems of toxicity and potential immunogenicity that are associated with other potential antiangiogenic drugs. Thus, these molecules can be delivered via targeted cell- or viral vector-based therapy.

\section{ACKNOWLEDGEMENTS}

We are tremendously grateful to Adara DeNiro for her valuable technical assistance in the preparation and word processing of the manuscript. In addition, we would like to thank Clive Gray for his seasoned design input throughout the various stages of this study.

\section{REFERENCES}

[1] Russ PK, Gaylord GM, Haselton FR. Retinal vascular permeability determined by dual-tracer fluorescence angiography. Ann Biomed Eng 2001; 29: 638-47.

[2] Barinaga M. Shedding light on blindness. Science 1995; 267: 4523.

[3] Stitt AW, Bhaduri T, McMullen CB, Gardiner TA, Archer DB. Advanced glycation end products induce blood-retinal barrier dysfunction in normoglycemic rats. Mol Cell Biol Res Commun 2000; 3: 380-8.

[4] Campochiaro PA. Retinal and choroidal neovascularization. J Cell Physiol 2000; 184: 301-10.

[5] Cross MJ, Dixelius J, Matsumoto T, Claesson-Welsh L. VEGFreceptor signal transduction. Trends Biochem Sci 2003; 28: 488-94.

[6] Thieme H, Aiello LP, Takagi H, Ferrara N, King GL. Comparative analysis of vascular endothelial growth factor receptors on retinal and aortic vascular endothelial cells. Diabetes 1995; 44: 98-10.

[7] Adamis AP, Miller JW, Bernal MT, et al. Increased vascular endothelial growth factor levels in the vitreous of eyes with proliferative diabetic retinopathy. Am J Ophthalmol 1994; 118: 445-50.

[8] Aiello LP, Avery RL, Arrigg PG, et al. Vascular endothelial growth factor in ocular fluid of patients with diabetic retinopathy and other retinal disorders. N Engl J Med 1994; 331: 1519-20.

[9] Aiello LP, Pierce EA, Foley ED, et al. Suppression of retinal neovascularization in vivo by inhibition of vascular endothelial growth factor (VEGF) using soluble VEGF-receptor chimeric proteins. Proc Natl Acad Sci USA 1995; 92: 10457-61.

[10] Ko FN, Wu CC, Kuo SC, Lee FY, Teng CM. YC-1, a novel activator of platelet guanylate cyclase. Blood 1994; 84: 4226-33.

[11] DeNiro M, Alsmadi O, Al-Halafi A, Al-Mohanna F. Pleiotropic Effects of YC-1 Attenuates Pathological Retinal Neovascularization. Invest Ophthalmol Vis Sci 2009a; E-Abstract \#41.

[12] DeNiro M, Alsmadi O, Al-Mohanna F. Modulating the hypoxiainducible factor signaling pathway as a therapeutic modality to regulate retinal angiogenesis. Exp Eye Res 2009b; (89): 700-17.

[13] Smith LE, Wesolowski E, McLellan A, et al. Oxygen-induced retinopathy in the mouse. Invest Ophthalmol Vis Sci 1994; 35: 101-11.

[14] DeNiro M, Al-Mohanna FH, Alsmadi O, and Al-Mohanna FA. pleiotropic effects of YC-1 selectively inhibits pathological retinal neovascularization and promotes physiological revascularization in a mouse model of oxygen-induced retinopathy. Mol Pharmacol 2010; 77: 348-67.

[15] Michaelson I. The mode of development of the vascular system of the retina with some observations on its significance for certain retinal diseases. Trans Ophthalmol Soc UK 1948; 68: 137-80.

[16] Wang Y, Vanderlaan M, Song A. Biological activity of bevacizumab, a humanized anti-VGEF antibody in vitro. Angiogenesis 2004; 7: 335-45.

[17] Folkman J. Anti-angiogenesis: new concept for therapy of solid tumors. Ann Surg 1972; 175: 409-16.

[18] Presta LG, O'Connor SJ. Humanization of an anti-VEGF monoclonal antibody for the therapy of solid tumors and other disorders. Cancer Res 1997; 57: 4593-9.

[19] Van Wijngaarden $P$, Williams K. Inhibitors of ocular neovascularization promises and potential problems. JAMA 2005; 293: $1509-13$.

[20] Warren RS, Matli, MR. Regulation by VEGF of human colon cancer tumorigenesis in a mouse model of experimental liver metastasis. J Clin Invest 1995; 95: 1789-97.

[21] Gordon MS, Talpaz M. Phase I safety and pharmacokinetic study of recombinant human anti-VEGF in patients with advanced cancer. J Clin Oncol 2001; 19: 843-50.

[22] Friedlander SM. Vanishing disc neovascularization following intravitreal bevacizumab (avastin) injection. Arch Ophthalmol 2006; 124: 13-65.

[23] Rosenfeld PJ. Optical coherence tomography findings after an intravitreal injection of bevacizumab (avastin) for neovascular agerelated macular degeneration. Ophthalmic Surg 2005; 36: 331-5.

[24] Avery RL, Pieramici DJ, Rabena MD, Castellarin AA, Nasir MA, Giust MJ. Intravitreal bevacizumab (Avastin) for neovascular agerelated macular degeneration. Ophthalmology 2006; 113: 363-72.

[25] Mordenti J, Ferrara N. Comparisons of the intraocular tissue distribution, pharmacokinetics, and safety of 125I-labeled full length and Fab antibodies in rhesus monkeys following intravitreal administration. Toxicol Pathol 1999; 27: 536 -44.

[26] Haritoglou C, Kook D. Intravitreal bevacizumab (Avastin) therapy for persistent diffuse diabetic macular edema. Retina 2006; 26 : 999-1005.

[27] Jorge R. Intravitreal bevacizumab (Avastin) for persistent new vessels in diabetic retinopathy (IBEPE study). Retina 2006; 26: 1006-13. 
[28] Michels S, Puliafito CA, Marcus EN, Venkatraman AS. Systemic bevacizumab (Avastin) therapy for neovascular age-related macular degeneration: twelve-week results of an uncontrolled open-label clinical study. Ophthalmology 2005; 112:1035-47.

[29] Blaauwgeers HG, Holtkamp GM, Rutten $\mathrm{H}$, et al. Polarized vascular endothelial growth factor secretion by human retinal pigment endothelium and localization of vascular endothelial growth factor receptor on the inner choriocapillaris. Evidence for a trophic paracrine relation. Am J Pathol 1999; 155: 421- 8.

[30] Peters S, Heiduschka P, Julian S, et al. Tubingen Bevacizumab Study Group. Ultrastructural findings in the primate eye after intravitreal injection of bevacizumab. Am J Ophthalmol 2007; 143: 995-1002.

[31] Rosenfeld PJ, Rich RM, Lalwani GA. Ranibizumab: Phase III clinical trial results. Ophthalmol Clin North Am 2006; 19: 361-72.

[32] Ishida S, Usui $\mathrm{T}$, Yamashiro $\mathrm{K}$, et al. VEGF 165-mediated information is required for pathological but not physiological ischaemia-induced retinal neovascularization. J Exp Med 2003; 198: 483-489.

[33] Cunningham ET Jr, Adamis AP, Altaweel M, et al; Macugen Diabetic Retinopathy Study Group. A phase II randomized doublemasked trial of pegaptanib, an anti-vascular endothelial growth factor aptamer, for diabetic macular edema. Ophthalmology 2005; 112: 1747-57.

[34] Nguyen QD, Shah SM, Haller JA, et al. Vascular endothelial growth factor is a critical stimulus for diabetic macular edema. Am J Ophthalmol 2006; 142: 961-9.

[35] Gaudrealt J, Rusit J, Suboc P, Shiu V. Preclinical pharmacokinetics of Ranibizumab (rhuFabV2) after a single intravitreal administration. Invest Ophthalmol Vis Sci 2005; 46: 726-33.

[36] Krohne TU, Holz FG, Meyer CH. Intraocular pharmacokinetics of bevacizumab after a single intravitreal injection in humans. Am J Ophthalmol 2008; 146: 508-12.

[37] Lockhart AC, Rothenberg ML, Dupont J, et al. Phase I study of intravenous vascular endothelial growth factor trap (aflibercept) in patient with advanced solid tumors. J Clin Oncol 2010; 28: 207-14.

[38] Rana TM. Illuminating the silence: understanding the structure and function of small RNAs. Nat Rev Mol Cell Biol 2007; 8: 23-36.

[39] Hadj-Slimane R, Lepelletier Y, Lopez N, Garbay C, Raynaud F. Short interfering RNA (siRNA), a novel therapeutic tool acting on angiogenesis. Biochimie 2007; 89: 1234-44.

[40] Reich SJ, Fosnot J, Kuroki A, et al. Small interfering RNA (siRNA) targeting VEGF effectively inhibits ocular neovascularization in a mouse model. Mol Vis 2003; 9: 210-16.

[41] Cashman SM, Bowman L, Christofferson J, Kumar-Singh R. Inhibition of choroidal neovascularization by adenovirus-mediated delivery of short hairpin RNAs targeting VEGF as a potential therapy for AMD. Invest Ophthalmol Vis Sci 2006; 47: 3496-504.

[42] Kleinman ME, Yamada K, Takeda A, et al. Sequence- and targetindependent angiogenesis suppression by siRNA via TLR3. Nature 2008; 452: 591-7.

[43] Xia XB, Xiong SQ, Song WT, Luo J, Wang YK, Zhou RR. Inhibition of retinal neovascularization by siRNA targeting VEGF (165). Mol Vis 2008; 14: 1965-73.

[44] Tolentino MJ, Brucker AJ, Fosnot J, et al. Intravitreal injection of vascular endothelial growth factor small interfering RNA inhibits growth and leakage in a nonhuman primate, laser-induced model of choroidal neovascularization. Retina 2004; 1: 132-8.

[45] Motzer RJ, Redman BG, Hudes GR, et al. Activity of SU11248, a multitargeted inhibitor of vascular endothelial growth factor receptor and platelet-derived growth factor receptor, in patients with metastatic renal cell carcinoma. J Clin Oncol 2006; 24: 16-24.

[46] Nakahara T, Shalinsky DR, Hu-Lowe DD, McDonald DM. Effect of inhibition of vascular endothelial growth factor signaling on distribution of extravasated antibodies in tumors. Cancer Res 2006; 66: 1434-45.

[47] Kelly RJ, Rixe O. Axitinib (AG-013736). Recent Results Cancer Res 2010; 184: 33-44.

[48] Rewolinski DA, Grove CG, Cartwright CA, et al. Analysis of angiogenic growth factors in rat retina following inhibition of VEGF-receptor 2. Invest Ophthalmol Vis Sci 2001; 42: S92-S92.

[49] Kinose F, Lamartina S, Anderson KD, et al. Inhibition of retinal and choroidal neovascularization by a novel KDR kinase inhibitor. Mol Vis 2005; 11: 366-73.

[50] Jo N, Ju M, Cheung E, et al. Inhibition of platelet-derived growth factor B signaling enhances the efficacy of anti-vascular endothelial growth factor therapy in multiple models of ocular neovascularization. Am J Pathol 2006; 168: 2036-53.

[51] Hoyng CB, Vingerling JR, Hooymans JM M, et al. AG-013958 (VEGFR inhibitor) achieves effective choroidal concentrations with minimal systemic effects in cynomolgus monkeys and humans with age-related macular disease. Invest Ophthalmol Vis Sci 2005; 46: E-Abstract 2365.

[52] Wang FE, Niesman MR, Rewolinski DA, Miller SS. Receptor tyrosine kinase inhibitors AG013764 and AG013711 reduce choroidal neovascularization in rat eye. Exp Eye Res 2007; 84: 922-33.

[53] Patel N, Moshinsky D, Chen H, et al. A selective and oral small molecule inhibitor of vascular epithelial growth factor receptor (VEGFR)-2 and VEGFR-1 inhibits neovascularization and vascular permeability. J Pharmacol Exp Ther 2003; 306: 838-45.

[54] Mendel DB, Xin X, Louie SG, et al. In vivo antitumor activity of SU11248, a novel tyrosine kinase inhibitor targeting vascular endothelial growth factor and platelet-derived growth factor receptors: determination of a pharmacokinetic/pharmacodynamic relationship. Clin Cancer Res 2003; 9: 327-37.

[55] Cao R, Jensen LDE, Söll I, Hauptmann G, Cao Y. Hypoxiainduced retinal angiogenesis in zebrafish as a model to study retinopathy. PLoS One 2008; 3: e2748.

[56] Whittles CE, Pocock TM, Wedge SR, et al. ZM323881, a novel inhibitor of vascular endothelial growth factor-receptor-2 tyrosine kinase activity. Microcirculation 2002; 6: 513-22.

[57] Endo A, Masuda M , Ohmori T, Mochizuki N. Selective inhibition of vascular endothelial growth factor receptor-2 (VEGFR-2) identifies a central role for VEGFR-2 in human aortic endothelial cell responses to VEGF. J Recept Signal Transduct Res 2003; 23: 239-54.

[58] Takagi $\mathrm{H}$, Koyama $\mathrm{S}$, Seike $\mathrm{H}$, et al. Potential role of the angiopoietin/tie2 system in ischemia-induced retinal neovascularization. Invest Ophthalmol Vis Sci 2003; 44: 393-402.

[59] Singh N, Rashid S, Ambati J, Kontos CD, Higgins E. Ambati BK. Systemic soluble Tie2 expression inhibits and regresses corneal neovascularization. Biochem Biophys Res Commun 2005; 332: 194-9.

[60] Alvarez Y, Jensen L, Reynolds AL, et al. Selective inhibition of retinal angiogenesis by targeting PI3 kinase. PLoS One 2009; 4: e7867.

[61] Nowak DG, Woolard J, Amin EM, et al. Expression of pro- and anti-angiogenic isoforms of VEGF is differentially regulated by splicing and growth factors. J Cell Sci 2008; 20: 3487-95.

[62] Hua J, Spee C, Baron E, et al. Therapeutic Potential of Small Molecule Splicing Factor-inhibitor Srpin340 in Treatment of Choroidal Neovascularization (CNV). Invest Ophthalmol Vis Sci 2009; E-2333.

[63] Emanuel S, Fuentes-Pesquera A, Connolly PJ, et al. A vascular endothelial growth factor receptor-2 kinase inhibitor potentiates the activity of the conventional chemotherapeutic agent's paclitaxel and doxorubicin in tumor xenograft models. Mol Pharmacol 2004; 66: 635-47.

[64] Emanuel S, Susan Hazel, Fuentes-Pesquera A, et al. Inhibition of angiogenesis and retinal neovascularization by an orally available vascular endothelial growth factor receptor inhibitor. Proc Amer Assoc Cancer Res 2005; 46: Abstract \#3863.

[65] Wang YH, Wang XR, Ni JS, Xin Y, Shi B, Wu JX. Effect of wortmannin on endothelial cell proliferation and migration induced by high glucose Müller cell conditioned medium. Zhonghua Bing Li Xue Za Zhi 2005; 34: 229-32.

[66] Kroll J, Kern K, Dietz CT, et al. Inhibition of Rho-dependent kinases ROCK I/II activates VEGF-driven retinal neovascularization and sprouting angiogenesis. Am J Physiol Heart Circ Physiol 2009; 296: H893-H899.

[67] Tura A, Monnier PP, Bartz-Schmidt KU, Henke-Fahle S. Efficacy of Rho-kinase inhibition in promoting cell survival and reducing reactive gliosis in the rodent retina. Invest Ophthalmol Vis Sci 2009; 50: 452-61.

[68] Ozaki H, Ozaki K, Yamada H, et al. Blockade of vascular endothelial cell growth factor receptor signaling is sufficient to completely prevent retinal neovascularization. Am J Pathol 2000; 156: 697-707.

[69] Maier P, Junker B, Martin G, Drevs J, Hansen LL, Agostini HT Intravitreal injection of specific receptor tyrosine kinase inhibitor 
PTK787/ZK222 584 improves ischemia-induced retinopathy in mice. Graefes Arch Clin Exp Ophthalmol 2005; 243: 593-600.

[70] Scheppke L, Aguilar E, Gariano RF, et al. Retinal vascular permeability suppression by topical application of a novel VEGFR2/Src kinase inhibitor in mice and rabbits. J Clin Invest 2008; 6: 2337-46.

[71] Noronha G, Boccia A, Brodhag T, et al. Discovery of [7-(2, 6dichlorophenyl)-5-methylbenzo $\quad[1, \quad 2, \quad 4]$ triazin-3-yl]-[4-(2pyrrolidin-1-ylethoxy)phenyl]amine--a potent, orally active Src kinase inhibitor with anti-tumor activity in preclinical assays. Med Chem Lett 2007; 17: 602-8.

[72] Fabbro D, Ruetz, S, Bodis, S, et al. PKC412-a protein kinase inhibitor with a broad therapeutic potential. Anti-Cancer Drug Des 2000; 15:17-28.

[73] Saishin Y, Takahashi K, Seo MS, Melia M, Campochiaro PA. The kinase inhibitor PKC412 suppresses epiretinal membrane formation and retinal detachment in mice with proliferative retinopathies. Invest Ophthalmol Vis Sci 2003; 44: 3656-62.

[74] Kernt M, Neubauer AS, Liegl RG, et al. Sorafenib prevents human retinal pigment epithelium cells from light-induced overexpression of VEGF, PDGF and PIGF. Br J Ophthalmol 2010; 11: 1533-9.

[75] Takahashi K, Saishin Y, Saishin Y, King AG, Levin R, Campochiaro PA. Suppression and regression of choroidal neovascularization by the multitargeted kinase inhibitor pazopanib. Arch Ophthalmol 2009; 4: 494-9.

[76] Hudson CC, Chiang GG, Otterness DM, et al. Regulation of hypoxia-inducible factor 1alpha expression and function by the mammalian target of rapamycin. Mol Cell Biol 2002; 22: 7004-14.

[77] Dutcher JP. Mammalian target of rapamycin (mTOR) Inhibitors. Curr Oncol Rep 2004; 2: 111-5.

[78] Dejneka NS, Fosnot J, Tang W, Tolentino MJ, Bennett J. Systemic rapamycin inhibits retinal and choroidal neovascularization in mice. Mol Vis 2004; 10: 964-72.

[79] Kwon YS, Kim JC, Shin JS, Son Y. Inhibitory effect of rapamycin on corneal neovascularization in vitro and in vivo. Invest Ophthalmol Vis Sci 2005; (46): 454-60.

[80] Nussenblatt RB, Byrnes G, Sen N, et al. A randomized pilot study of systemic immunosuppression in the treatment of age-related macular degeneration with choroidal neovascularization. Retina 2010; 10: 1579-87.

[81] An WG, Schulte TW, Neckers LM. The heat shock protein 90 antagonist geldanamycin alters chaperone association with p210bcr-abl and v-src proteins before their degradation by the proteasome. Cell Growth Differ 2000; 11(7): 355-60.

[82] Sausville EA. Combining cytotoxics and 17-allylamino, 17demethoxygeldanamycin: sequence and tumor biology matters. Clin Cancer Res 2001; 7: 2155-8.

[83] Kociok N, Poulaki V, Joussen A. Geldanamycin treatment reduces neovascularization in a mouse model of retinopathy of prematurity. Graefe's Arch Clin Exp Ophthalmol 2007; 245: 258-66.

[84] Zhang Y, Griffith EC, Sage J, Jacks T, Liu JO. Cell cycle inhibition by the anti-angiogenic agent UTNP-470 is mediated by p53 and p21WAF1/CIP1. Proc Natl Acad Sci USA 2000; 12: 6427-32.

[85] Castronovo V, Belotti D. TNP-470 (AGM-1470): mechanisms of action and early clinical development. Eur J Cancer 1996; 32A: 2520-7.

[86] Yasukawa T, Tabata Y, Miyamoto H, Honda Y, Ikada Y, Ogura Y. Targeted delivery of anti-angiogenic agent TNP-470 using watersoluble polymer in the treatment of choroidal neovascularization. Invest Ophthalmol Vis Sci 1999; 40: 2690-6.

[87] Falkenstein IA, Cheng L, Wong-Staal F, et al. Toxicity and intraocular properties of a novel long-acting anti-proliferative and anti-angiogenic compound IMS2186. Curr Eye Res 2008; 7: 599609.

[88] Fernandez-Tornero C, Redondo-Horcajo M, Gomez AM, et al. Leads for development of new naphthalenesulfonate derivatives with enhanced antiangiogenic activity: crystal structure of acidic fibroblast growth factor in complex with 5-amino-2-naphthalene sulfonate. J Biol Chem 2003; 278: 21774-81.

[89] Lange C, Martin G, Konzok K, Moscoso Del Prado J, Hansen LL, Agostini HT. Intravitreal injection of the heparin analog 5-amino2-naphthalenesulfonate reduces retinal neovascularization in mice. Exp Eye Res 2007; 85: 323-7.

[90] Afzal A, Palii SS, Jurczyk S, et al. Targeting retinal and choroid neovascularization using the small molecule inhibitor carboxyamidotriazole. Brain Res Bull 2010; 81: 320-6.
[91] Xin X, Kowalski J, Gerritsen ME. Peroxisome proliferatoractivated receptor gamma ligands are potent inhibitors of angiogenesis in vitro and in vivo. J Biol Chem 1999; 274: 9116-21.

[92] Murata T, Hata Y, Ishibashi T, et al. Response of experimental retinal neovascularization to thiazolidinediones. Arch Ophthalmol 2001; 119: 709-17

[93] Nambu H, Nambu R, Melia M, Campochiaro PA. Combretastatin A-4 phosphate suppresses development and induces regression of choroidal neovascularization. Invest Ophthalmol Vis Sci 2003; 8: 3650-5.

[94] Nandrot EF, Sircar M, Finnemann SC. Novel role for alphavbeta5integrin in retinal adhesion and its diurnal peak. Am J Physiol Cell Physiol 2006; 290: C1256-C62.

[95] Nandrot EF, Finnemann SC. Alphavbeta5-integrin receptors at the apical surface of the RPE: one receptor, two functions. Adv Exp Med Biol 2008; 613: 369-75.

[96] Thumann G, Hoffmann S, Hinton DR. Cell biology of the retinal pigmented epithelium. In: Ryan SJ, Ed. Retina. St. Louis, MO Mosby; 2005: pp. 137-52.

[97] Charteris DG, Aylward GW, Sethi C, Luthert P. Intraretinal and periretinal pathology in anterior proliferative vitreoretinopathy. Graefes Arch Clin Exp Ophthalmol 2007; 245: 93-100.

[98] Hiscott P, Magee RM, Grierson I. Matrix and the retinal pigment epithelium in proliferative retinal disease. Prog Retin Eye Res 1999; 18: 167-90.

[99] Stragies R, Zischinsky G. Design and synthesis of a new class of selective integrin alpha5beta1 antagonists. J Med Chem 2007; 50: 3786-94.

[100] Zahn G, Stragies R. Preclinical evaluation of the novel smallmolecule integrin alpha5beta1 inhibitor JSM6427 in monkey and rabbit models of choroidal neovascularization. Arch Ophthalmol 2009; 127: 1329-35.

[101] Umeda N, Akiyama H. Suppression and regression of choroidal neovascularization by systemic administration of an alpha5betal integrin antagonist. Mol Pharmacol 2006; 69: 1820-8.

[102] Capone Jr. A, Gonzalez VH, Heier JS, et al. A Phase I Open-Label Study of Single and Repeated Doses of Intravitreal JSM6427, a Small Molecule Integrin 5 $\beta 1$ Antagonist, in Neovascular AgeRelated Macular Degeneration (AMD). Invest Ophthalmol Vis Sci 2009; ARVO E-Abstract \#1259.

[103] Berka JL, Wang DZM, DiNicolantonio R, Alcorn D, Campbell DJ, Skinner SL. Renin-containing Müller cells of the retina display endocrine features. Invest Ophthalmol Vis Sci 1995; 36: 1450-8.

[104] Danser AHJ, Admiraal PJJ, Deinum J, Dejong P, Schalekamp M. Angiotensin levels in the eye. Invest Ophthalmol Vis Sci 1994; 35: 1008-18.

[105] Le Noble FA, Van Straaten HW, Slaaf DW, Stryker Boudier HA. Angiotensin II stimulates angiogenesis in the chorioallantoic membrane of the chick embryo. Eur J Pharmacol 1991; 195: 305-6.

[106] De Gasparo M, Inagami T, Wright JW, Unger T. Internationa union of pharmacology XXIII. The angiotensin II receptors. Pharmacol Rev 2000; 52: 415-72.

[107] Tamarat R, Durie M, Levy BI. Angiotensin II angiogenic effect in vivo involves vascular endothelial growth factor-and inflammationrelated pathways. Lab Invest 2002; 82: 747-56.

[108] Moravski CJ, Cooper ME. Retinal neovascularization is prevented by blockade of the renin-angiotensin system. Hypertension 2000; 36: 1099-104.

[109] Lonchampt M, Duhault J. Hyperoxia/normoxia-driven retinal angiogenesis in mice: a role for angiotensin II. Invest Ophthalmol Vis Sci 2001; 42: 429-32.

[110] Otani A, Suzuma K, Honda Y. Angiotensin II potentiates vascular endothelial growth factor-induced angiogenic activity in retinal microcapillary endothelial cells. Circ Res 1998; 82: 619-28.

[111] Nagai N, Urano T, Kubota Y, et al. Selective suppression of pathologic, but not physiologic, retinal neovascularization by blocking the angiotensin II type 1 receptor. Invest Ophthalmol Vis Sci 2005; 46: 1078-84

[112] Tadesse M, Yan Y, Yossuck P, Higgins RD. Captopril improves retinal neovascularization via endothelin-1. Invest. Ophthalmol Vis Sci 2001; 42: 1867-72.

[113] Okamura A, Ohishi M. Upregulation of renin-angiotensin system during differentiation of monocytes to macrophages. J Hypertens 1999; 17: 537-45.

[114] UK Prospective Diabetes Study (UKPDS) Group. Intensive bloodglucose control with sulphonylureas or insulin compared with 
conventional treatment and risk of complications in patients with type 2 diabetes (UKPDS 33). Lancet 1998; 352: 837-53.

[115] Funatsu H, Nakanishi Y, Hori S. Angiotensin II and vascular endothelial growth factor in the vitreous fluid of patients with proliferative diabetic retinopathy. Br J Ophthalmol 2002; 86: 3115.

[116] Nakamura H, Ohyama $\mathrm{T}$, Inoue $\mathrm{T}$, Arakawa $\mathrm{N}$, Domon $\mathrm{Y}$, Yokoyama T. Role of angiotensin II type 1 receptor on retinal vascular leakage in a rat oxygen-induced retinopathy model. Ophthalmic Res 2009; 41: 210-5.

[117] Davies RO, Gomez HJ, Irvin JD, Walker JF. An overview of the clinical pharmacology of enalapril. Br J Clin Pharmacol 1984; 18 (Suppl 2): 215S-229S.

[118] Bicket D. Using ACE inhibitors appropriately. Am Fam Phys 2003; 66: 461-8.

[119] Kitambi SS, Peterson RT, Malicki JJ. Small molecule screen for compounds that affect vascular development in the zebrafish retina. Mech Dev 2009; 126: 464-77.

[120] Mauer M, Zinman B, Gardiner R, et al. Renal and retinal effects of enalapril and losartan in type 1 diabetes. N Engl J Med 2009; 1: 4051.

[121] Chaturvedi N, Sjolie AK, Stephenson JM, et al. Effect of lisinopril on progression of retinopathy in normotensive people with type 1 diabetes. The EUCLID Study Group. EURODIAB Controlled Trial of Lisinopril in Insulin-Dependent Diabetes Mellitus. Lancet 1998; 351: 28-31.

[122] Sarlos S, Moravski CJ, Cao Z, Cooper ME, Wilkinson-Berka JL. Retinal angiogenesis is mediated by an interaction between the angiotensin type 2 receptor, VEGF, and angiopoietin. Am J Pathol 2003; 163: 879-87.

[123] Gilbert RE, Berka JL, Kelly DJ, et al. Vascular endothelial growth factor and its receptors in control and diabetic rat eyes. Lab Invest 1998; 78: 1017-27.

[124] Chaturvedi N, Porta M, Klein R, et al. Effect of candesartan on prevention (DIRECT-Prevent 1) and progression (DIRECT Protect 1) of retinopathy in type 1 diabetes: randomised, placebocontrolled trials. Lancet 2008; 372: 1394-1402.

[125] Sjølie AK, Klein R, Porta M, et al. Effect of candesartan on progression and regression of retinopathy in type 2 diabetes (DIRECT-Protect 2): a randomised placebo controlled trial. Lancet 2008; 372: 1385-93.

[126] Alzaid AA, Dinneen SF, Melton LJ 3rd, Rizza RA. The role of growth hormone in the development of diabetic retinopathy. Diabetes Care 1994; 17: 531-4.

[127] Kohner EM. Diabetic retinopathy. Metabolism 1975; 24: 1085-102.

[128] Merimee T. A follow-up study of vascular disease in growthhormone-deficient dwarfs with diabetes. N Engl J Med 1978; 298: 1217-22.

[129] Hansen R, Malozowski S. Full remission of growth-hormone (GH)induced retinopathy after $\mathrm{GH}$ treatment discontinuation: long-term follow-up. J Clin Endocrinol Metab 2000; 85: 26-7.

[130] Smith LE, Chen W, Knapp J, et al. Essential role of growth hormone in ischemia-induced retinal neovascularization. Science 1997; 276: 1706-9.
[131] Growth Hormone Antagonist for Proliferative Diabetic Retinopathy Study Group. The effect of a growth hormone receptor antagonist drug on proliferative diabetic retinopathy. Ophthalmology 2001; 108: 2266-72.

[132] Higgins RD, Schrier BK. Somatostatin analogs inhibit neonatal retinal neovascularization. Exp Eye Res 2002; 74: 553-9.

[133] Wilkinson-Berka JL, Jaworski K, Ninkovic S, Tachas G, Wraight CJ. An antisense oligonucleotide targeting the growth hormone receptor inhibits neovascularization in a mouse model of retinopathy. Mol Vis 2007; 13: 1529-38.

[134] Nussenblatt RB, Whitcup SM, de Smet MD, et al. Intraocular inflammatory disease (uveitis) and the use of oral tolerance: a status report. Ann N Y Acad Sci 1996; 778: 325-37.

[135] Cunningham MA, Edelman JL, Kaushal S. Intravitreal steroids for macular edema: the past, the present, and the future. Surv Ophthalmol 2008; 53: 139-49.

[136] Kaur C, Foulds WS, Ling EA. Blood-retinal barrier in hypoxic ischaemic conditions: basic concepts, clinical features and management. Prog Retin Eye Res 2008; 6: 622-47.

[137] Martidis A, Puliafito CA. Intravitreal triamcinolone for refractory cystoid macular edema secondary to birdshot retinochoroidopathy. Arch Ophthalmol 200; 119: 1380-3.

[138] Degenring RF. Intravitreal injection of triamcinolone acetonide as treatment for chronic uveitis. Br J Ophthalmol 2003; 87: 361.

[139] Jonas JB, Degenring R. Intravitreal triamcinolone acetonide as an additional tool in pars plana vitrectomy for proliferative diabetic retinopathy. Eur J Ophthalmol 2003; 13: 468-73.

[140] Edelman JL, Lutz D, Castro MR. Corticosteroids inhibit VEGFinduced vascular leakage in a rabbit model of blood-retinal and blood-aqueous barrier breakdown. Exp Eye Res 2005; 80: 249-58.

[141] Kogure A, Kogure S, Yamaguchi T, Kishi S. Efficacy and retention times of intravitreal triamcinolone acetonide for macular edema. Jpn J Ophthalmol 2008; 52: 122-6.

[142] Gillies MC, Simpson JM, Larson J, Ali H, Zhu M. Intravitreal triamcinolone for refractory diabetic macular edema: two-year results of a double-masked, placebo controlled, randomized clinical trial. Ophthalmology 2006; 113: 1533-8.

[143] Diabetic Retinopathy Clinical Research Network. A randomized trial comparing intravitreal triamcinolone acetonide and focal/grid photocoagulation for diabetic macular edema. Ophthalmology 2008; 115: 1447-9.

[144] Sherif Z. Corticosteroids in Ophthalmology: past, present and future. Ophthalmologica 2002; 216: 305-15.

[145] Kersey JP. Corticosteroid-induced glaucoma: a review of the literature. Eye 2006; 20: 407-16.

[146] Wordinger RJ. Effects of glucocorticoids on the trabecular meshwork: Towards a better understanding of glaucoma. Prog Retin Eye Res 1999; 18: 629-67.

[147] Otani A, Slike BM, Dorrell MI, et al. A fragment of human TrpRS as a potent antagonist of ocular angiogenesis. Proc Natl Acad Sci USA $2002 ; 1: 178-83$.

(C) DeNiro and Al-Mohanna.; Licensee Bentham Open.

This is an open access article licensed under the terms of the Creative Commons Attribution Non-Commercial License (http://creativecommons.org/licenses/by-nc/3.0/) which permits unrestricted, non-commercial use, distribution and reproduction in any medium, provided the work is properly cited. 